\title{
WHICH FACTORS DETERMINE THE CAPITAL STRUCTURE OF NON-FINANCIAL PUBLICLY TRADED IRISH FIRMS?
}

\author{
Julie Byrne \\ Michael Smurfit Graduate Business School, University College Dublin, Dublin 4 \\ and \\ Bridget McNally and Thomas O'Connor \\ Department of Economics, Finance and Accounting National University of Ireland \\ Maynooth
}

\begin{abstract}
Tn this paper, we trace the indebtedness of the non-financial corporate sector in Ireland over the period from 1980 to 2007. This period witnessed an episode of leveraging to 2001, followed by a period of deleveraging to 2007. Our findings suggest that fundamentals can help explain why firms became more indebted between 1980 and 2001, but the deleveraging that took place after 2001 is due to factors other than the fundamentals included in our analysis. While we cannot say definitively, our findings may be in line with evidence that points to a concerted effort on the part of Irish firms since 2001 to reduce their debt financing.
\end{abstract}

\section{INTRODUCTION}

High debt levels and the exact maturity profile of that debt can leave the non-financial corporate sector vulnerable to risks related, for whatever reasons, to a reduced supply of and/or an increased cost of debt financing (Almeida, Campello, Larenjera and Weisbenner, 2011), which can ultimately provide a drag on economic growth and even threaten the very stability of the macroeconomy (Cecchetti, Mohanty and Zampolli, 2011). For example, many commentators cited excessive corporate debt levels prior to the Asian crisis as a contributory cause of that crisis (Harvey and Roper, 1999; Krugman, 1999; Claessens, Djankov and L. Xu, 2000), while firms whose debt was predominantly short-term experienced the largest 
declines in investment during the current credit crisis (Duchin, Ozbas and Sensoy, 2010). However, the recent crisis also highlights the fact that long-term debt financing does not necessarily mitigate against rollover risk if a sizable proportion of that long-term debt matures at the same time as the supply of financing is reduced. ${ }^{1}$ Hence the level of debt, and the maturity structure of that debt is of primary concern to corporate financial managers.

In recent times, the focus has shifted away from emerging market non-financial firms to the capital structures of non-financial European firms. In particular, the balance sheets of non-financial Irish corporations have attracted considerable attention (McKinsey \& Co., 2012; International Monetary Fund, 2013). In fact, as recently as January 2013, the Central Bank of Ireland reported that Irish firms are the second-most indebted in Europe (Cussen and O'Leary, 2013). However, these findings almost always use debt-to-GDP to measure the level of debt and so the activities of multinational corporations in Ireland will heavily influence the results. When measured relative to the size of their balance sheets, the levels of debt of domestic, non-financial Irish firms fall below the European average (see the comparisons made in, among others, Fan, Titman and Twite, 2012). The ratio of debt to total assets includes fixed and financial assets and is a comprehensive measure of debt, seeing as such assets generate income and will, presumably, be sold if necessary. In the Irish context, while much of the emphasis has been placed on comparing the non-financial corporate-debt position in Ireland to the situation in other countries, very little attention has been given to the study of the evolution of non-financial Irish corporate debt over time, and more important, to its determinants. The sole exception is the study by Cussen and O'Leary (2013). However, their focus is on identifying supply-side effects, and they largely ignore how demand-side firmlevel fundamental factors may have influenced non-financial, Irish corporate debt levels over time. ${ }^{2}$ What we do not know is whether the increased use of debt financing was excessive, or whether it was justified in the sense that it was warranted based on changing firm-fundamentals, which would suggest the greater use of debt financing.

Multi-country studies have been used to compare differences in the capital structure of firms between countries, and the findings are consistently that both firm-specific and country-specific factors influence the capital structure of firms (see, for example, Rajan and Zingales (1995); Demirguc-Kunt and Maksimovic (1999); Booth, Aivazian, Demirguc-Kunt and Maksimovic (2001)). In an international study, Wald (1999) examines how firm-characteristics affect the capital structure of firms across countries, and finds that differences are associated with variations in agency costs and taxation policies. De Jong, Kabir and Nguyen (2008) find evidence that both firm-specific and country-specific factors influence a firm's capital structure, and that country-specific factors affect corporate leverage both directly and indirectly (through the effect they have on firm-specific factors).

In this paper, we examine whether fundamental factors can explain the use of debt financing by non-financial Irish firms. Using the book and market values of debt, we examine the period 1980 to 2007 and find that the average Irish non-financial firm is no more indebted than the European average and has debt levels well below 
those that may cause the firm to incur costs of financial distress. ${ }^{3}$ We begin by considering four fundamental factors that may explain firm-level determinants of debt, namely firm-size, profitability, asset tangibility and growth opportunities (Rajan and Zingales, 1995; Mitton, 2007), as well as four fundamental country-level determinants of debt - stock-market development, credit-market development, financial openness and creditor rights. We extend our analysis to examine how debt ratios of non-financial Irish firms evolve over time. We find that the median Irish nonfinancial firm is less indebted at the end of our sample period than at the beginning, but, over the entire sample period, Irish firms experienced a sustained period where they used considerably more leverage, followed by what is commonly referred to as a period of 'deleveraging'. Debt ratios increased over the period 1980 to 2001, peaking in 2001. This was followed by a period of deleveraging, resulting in a decline in debt ratios to pre-1980s levels. Thus, the sample period presents an excellent opportunity to examine whether fundamental determinants of debt financing can equally explain both episodes of corporate leveraging and deleveraging.

To do so, we estimate a series of one- and two-way fixed-effects regressions to examine how changes in debt over time are related to changes in these fundamental factors. We find that fundamental factors do matter, and can explain the debt ratios of Irish firms. These findings are in line with Rajan and Zingales (1995) and Mitton (2007), among others. On closer inspection, our findings are that while changes in firm- and country-fundamentals can explain the increase in debt financing between 1980 and 2001, they cannot explain the deleveraging in the period after 2001. In fact, we find that in the latter period, debt decreases even though fundamentals suggest that it should increase.

So what may explain the deleveraging of Irish firms since 2001? On the one hand, some of the explanations put forward for the deleveraging seen after the recent financial crisis do not apply in this case. For example, one of the arguments for the deleveraging of non-financial firms across the Eurozone since 2008 is that there is less access to credit, and not just bank credit, both domestically and internationally (Kahle and Stulz, 2012). Since the financial crisis began, banks have increased excess reserves and reduced lending, while investors have demanded higher-risk premia to extend credit and provide equity financing. The deleveraging of nonfinancial Irish firms, however, took place from 2001 to 2007 at a time of rapid growth in the Irish economy, where access to credit was increasing, both domestically and internationally. On the other hand, corporate deleveraging since 2008 is, in part, the result of a greater propensity on the part of firms to retain earnings (European Central Bank, February 2012). All else being equal, higher retention ratios result in a lower external financing need. ${ }^{4}$ This explanation may, at least, partly explain the deleveraging of Irish firms since 2001, and suggests that there has been a concerted effort by financial managers to reduce debt levels since 2001. In fact, there is some evidence, outlined in the main text, which supports this view.

The paper proceeds as follows. In section 2, we discuss our data. We present and discuss our empirical findings in section 3 . Section 4 concludes. 


\section{DATA}

We begin our study by sourcing a full list of Irish firms from the country lists of Worldscope over the period 1980 to 2007. All data is gathered on 31 December each year and includes all firms that are both active and inactive (dead stocks) in each year of our sample period. Like Mitton (2007) and others, we use two measures of debt, namely, book value of debt, defined as total debt to book value of assets, and market value of debt, calculated as total debt to market value of assets, where market value of assets is equal to total book assets less the book value of equity plus market capitalisation. Our final sample is comprised of 56 firms, which are firms that are currently trading (as of 2007), or have traded on the Irish Stock Exchange over some period of time between 1980 and 2007. All 56 firms satisfy our minimum data requirement that balance-sheet data, which includes measures of corporate debt (book and market) along with its determinants (firm-size, profitability, growth opportunities and asset tangibility), is available for each firm for at least two years over the entire sample period. Table 1 presents summary statistics for the full sample of 56 firms. We report summary measures for book and market debt, and supplement these measures with measures of long- and short-term debt to assets in order to capture the maturity structure of Irish corporate debt portfolios. Panel A reports summary measures for the level of debt and debt maturity. Panel B does the same for the range of debt, where the range is calculated for each firm as the difference between their maximum and minimum debt (or debt maturity) ratio measured over the entire sample period. Table 1 suggests the average or median Irish firm(s) are

TABLE I: SUMMARY STATISTICS

\begin{tabular}{|c|c|c|c|c|c|c|c|}
\hline & \multicolumn{7}{|c|}{ Panel A } \\
\hline & \multicolumn{7}{|c|}{ Level of debt and debt maturity } \\
\hline & Average & Median & $\begin{array}{c}\text { Std. } \\
\text { deviation }\end{array}$ & $\begin{array}{l}\text { Mini- } \\
\text { mum }\end{array}$ & $\begin{array}{l}\text { Maxi- } \\
\text { mum }\end{array}$ & $\begin{array}{c}25 \text { th } \\
\text { percentile }\end{array}$ & $\begin{array}{c}\text { 75th } \\
\text { Percentile }\end{array}$ \\
\hline Book debt & 0.248 & 0.240 & 0.175 & 0.000 & 0.826 & 0.113 & 0.349 \\
\hline Market debt & 0.202 & 0.179 & 0.160 & 0.000 & 0.785 & 0.083 & 0.286 \\
\hline LTD assets & 0.176 & 0.050 & 0.076 & 0.000 & 0.724 & 0.029 & 0.272 \\
\hline STD assets & 0.070 & 0.050 & 0.076 & 0.000 & 0.427 & 0.019 & 0.093 \\
\hline \multirow[t]{4}{*}{ LTD total } & 0.586 & 0.672 & 0.334 & 0.000 & 1.000 & 0.346 & $0.86 I$ \\
\hline & \multicolumn{7}{|c|}{ Panel B } \\
\hline & \multicolumn{7}{|c|}{ Range of debt and debt maturity } \\
\hline & Average & Median & $\begin{array}{c}\text { Std. } \\
\text { deviation }\end{array}$ & $\begin{array}{l}\text { Mini- } \\
\text { mum }\end{array}$ & $\begin{array}{l}\text { Maxi- } \\
\text { mum }\end{array}$ & $\begin{array}{c}\text { 25th } \\
\text { percentile }\end{array}$ & $\begin{array}{c}\text { 75th } \\
\text { Percentile }\end{array}$ \\
\hline Book debt & 0.303 & 0.281 & 0.187 & 0.000 & 0.825 & 0.184 & 0.385 \\
\hline Market debt & 0.313 & $0.34 I$ & 0.191 & 0.000 & 0.697 & 0.191 & 0.448 \\
\hline LTD assets & 0.274 & 0.269 & 0.191 & 0.000 & 0.724 & 0.159 & 0.385 \\
\hline STD assets & 0.149 & 0.122 & 0.117 & 0.000 & 0.427 & 0.077 & 0.190 \\
\hline LTD total & 0.661 & 0.760 & 0.252 & 0.000 & 1.000 & 0.476 & 0.869 \\
\hline
\end{tabular}


Which Factors Determine the Capital Structure of Non-Financial Publicly Traded Irish Firms?

Table I presents summary statistics for the level (Panel A) and range (Panel B) of debt and debt maturity for a sample of 56 firms listed on the Irish Stock Exchange over the period from 1980 to 2007. Debt is measured as either book debt or market debt. Book debt is total debt to total assets. Market debt is calculated as total debt to market value of assets, where market value of assets is equal to total book assets less the book value of equity plus market capitalisation. Debt maturity is both long- or short-term debt to total assets, and long-term debt to total debt, as indicated. The range is the difference between the maximum and minimum level of debt and debt maturity. All debt and debt maturity data is sourced from Worldscope.

not heavily indebted, in the sense that, for the median or average firm, book and market-debt ratios are well below levels considered to be high (or close to levels that may cause the firm to incur costs of financial distress). When comparisions are made across countries (Fan et al., 2012), the median Irish firm tends to be much less indebted when compared to firms from 38 other developed and developing countries. Also consistent with the evidence presented in Fan et al. is that Irish debt tends to be more long-term in nature.

Summary statistics for all 56 firms are provided in Table 2. A number of features evident from Table 2 are worth noting. First, the sample coverage varies significantly

TABLE 2: LEVEL AND RANGE OF DEBT AND DEBT MATURITY

\begin{tabular}{|c|c|c|c|c|c|c|c|c|c|}
\hline \multirow[t]{2}{*}{ Firm } & \multirow[t]{2}{*}{ Coverage } & \multicolumn{4}{|c|}{ Median } & \multicolumn{4}{|c|}{ Range } \\
\hline & & BD & MD & LTD & STD & BD & MD & LTD & STD \\
\hline Abbey & $82-07$ & 0.091 & 0.084 & 0.000 & 0.062 & 0.373 & 0.410 & 0.311 & 0.195 \\
\hline Aer Lingus & $00-07$ & 0.357 & 0.456 & 0.291 & 0.043 & 0.184 & 0.333 & 0.159 & 0.062 \\
\hline AGI & $06-07$ & 0.000 & 0.000 & 0.000 & 0.000 & 0.000 & 0.000 & 0.000 & 0.000 \\
\hline Arcon & $89-03$ & 0.410 & 0.320 & 0.292 & 0.048 & 0.644 & 0.571 & 0.654 & 0.421 \\
\hline Arnotts & $81-03$ & 0.105 & 0.140 & 0.079 & 0.041 & 0.201 & 0.438 & 0.190 & 0.097 \\
\hline Barlo & $88-03$ & 0.147 & 0.119 & 0.068 & 0.051 & 0.363 & 0.495 & 0.258 & 0.237 \\
\hline Bula & $00-01$ & 0.000 & 0.000 & 0.000 & 0.000 & 0.000 & 0.000 & 0.000 & 0.000 \\
\hline$C \& C$ & $01-07$ & 0.673 & 0.785 & 0.609 & 0.044 & 0.451 & 0.697 & 0.381 & 0.039 \\
\hline Calyx & $02-06$ & 0.474 & 0.387 & 0.318 & 0.149 & 0.283 & 0.312 & 0.216 & 0.144 \\
\hline Celtic resources & $02-06$ & 0.189 & 0.085 & 0.108 & 0.053 & 0.229 & 0.171 & 0.179 & 0.101 \\
\hline CPL resources & $99-07$ & 0.055 & 0.031 & 0.017 & 0.042 & 0.120 & 0.069 & 0.077 & 0.061 \\
\hline $\mathrm{CRH}$ & $80-07$ & 0.334 & 0.262 & 0.281 & 0.052 & 0.291 & 0.214 & 0.267 & 0.154 \\
\hline Datalex & $02-07$ & 0.057 & 0.055 & 0.000 & 0.057 & 0.133 & 0.160 & 0.000 & 0.132 \\
\hline DCC & $94-07$ & 0.272 & 0.216 & 0.168 & 0.068 & 0.281 & 0.220 & 0.346 & 0.159 \\
\hline Donegal & $98-07$ & 0.161 & 0.171 & 0.098 & 0.068 & 0.269 & 0.354 & 0.160 & 0.177 \\
\hline Dragon Oil & $90-07$ & 0.040 & 0.029 & 0.000 & 0.033 & 0.282 & 0.504 & 0.162 & 0.174 \\
\hline Eircom & $99-06$ & 0.558 & 0.433 & 0.523 & 0.029 & 0.566 & 0.633 & 0.563 & 0.104 \\
\hline Elan & $89-07$ & 0.355 & 0.132 & 0.325 & 0.025 & 0.825 & 0.691 & 0.723 & 0.220 \\
\hline Fyffes & $86-07$ & 0.270 & 0.211 & 0.144 & 0.115 & 0.251 & 0.229 & 0.176 & 0.301 \\
\hline Glanbia & $87-07$ & 0.299 & 0.248 & 0.244 & 0.049 & 0.281 & 0.367 & 0.347 & 0.138 \\
\hline Glencar & $00-01$ & 0.826 & 0.785 & 0.362 & 0.307 & 0.000 & 0.000 & 0.724 & 0.240 \\
\hline Grafton & $87-07$ & 0.302 & 0.236 & 0.210 & 0.086 & 0.288 & 0.199 & 0.284 & 0.098 \\
\hline Greencore & $86-07$ & 0.300 & 0.270 & 0.171 & 0.041 & 0.435 & 0.510 & 0.443 & 0.427 \\
\hline
\end{tabular}


TABLE 2 (CONTINUED)

\begin{tabular}{|c|c|c|c|c|c|c|c|c|c|}
\hline \multirow[t]{2}{*}{ Firm } & \multirow[t]{2}{*}{ Coverage } & \multicolumn{4}{|c|}{ Median } & \multicolumn{4}{|c|}{ Range } \\
\hline & & BD & MD & LTD & STD & BD & MD & LTD & STD \\
\hline Horizon & $97-07$ & 0.126 & 0.091 & 0.006 & 0.115 & 0.347 & 0.365 & 0.052 & 0.324 \\
\hline laws & $89-07$ & 0.248 & 0.132 & 0.214 & 0.029 & 0.253 & 0.291 & $0.27 I$ & 0.190 \\
\hline Icon & $98-07$ & 0.028 & 0.022 & 0.002 & 0.025 & 0.137 & 0.062 & 0.074 & 0.087 \\
\hline $\begin{array}{l}\text { Independent } \\
\text { News \& Media }\end{array}$ & $81-07$ & 0.309 & 0.284 & 0.289 & 0.040 & 0.469 & 0.348 & 0.392 & 0.134 \\
\hline lona & $98-07$ & 0.000 & 0.000 & 0.000 & 0.000 & 0.000 & 0.000 & 0.000 & 0.000 \\
\hline Irish Continental & $89-07$ & 0.344 & 0.291 & 0.294 & 0.047 & 0.443 & 0.410 & 0.426 & 0.098 \\
\hline IWP & $89-05$ & 0.357 & 0.185 & 0.256 & 0.069 & 0.416 & 0.482 & 0.499 & 0.261 \\
\hline Jurys Doyle & $86-04$ & 0.228 & 0.271 & 0.200 & 0.047 & 0.349 & 0.386 & 0.370 & 0.091 \\
\hline Kenmare & $95-99$ & 0.459 & 0.169 & 0.458 & 0.000 & 0.493 & 0.248 & 0.493 & 0.001 \\
\hline Kerry & $86-07$ & 0.329 & 0.207 & 0.297 & 0.036 & 0.253 & 0.194 & 0.305 & 0.142 \\
\hline Kingspan & $89-07$ & 0.239 & 0.143 & 0.152 & 0.078 & 0.269 & 0.226 & 0.280 & 0.141 \\
\hline Mclnerney & $85-07$ & 0.307 & 0.244 & 0.139 & 0.191 & 0.331 & 0.255 & 0.363 & 0.395 \\
\hline Minmet & $03-06$ & 0.000 & 0.000 & 0.000 & 0.000 & 0.000 & 0.000 & 0.000 & 0.000 \\
\hline Newcourt & $03-07$ & 0.265 & 0.229 & 0.146 & 0.114 & 0.232 & $0.50 \mathrm{I}$ & 0.177 & 0.077 \\
\hline Norish & $86-07$ & 0.284 & 0.270 & 0.168 & 0.086 & 0.323 & 0.421 & 0.374 & 0.161 \\
\hline Norkom & $04-07$ & 0.193 & 0.355 & 0.165 & 0.008 & 0.383 & 0.484 & 0.390 & 0.047 \\
\hline Oglesby \& Butler & $96-07$ & 0.041 & 0.044 & 0.019 & 0.022 & 0.126 & 0.093 & 0.024 & 0.112 \\
\hline Paddy Power & $99-07$ & 0.000 & 0.000 & 0.000 & 0.000 & 0.023 & 0.056 & 0.018 & 0.018 \\
\hline Petroceltic & $85-06$ & 0.000 & 0.000 & 0.000 & 0.000 & 0.144 & 0.077 & 0.057 & 0.086 \\
\hline Prime Active & $96-06$ & 0.368 & 0.458 & 0.243 & 0.116 & 0.548 & $0.48 \mathrm{I}$ & 0.549 & 0.109 \\
\hline Providence & $98-06$ & 0.111 & 0.046 & 0.039 & 0.000 & 0.385 & 0.238 & 0.385 & 0.110 \\
\hline Qualceram & $98-07$ & 0.280 & 0.259 & 0.000 & 0.186 & 0.497 & 0.524 & 0.422 & 0.302 \\
\hline Readymix & $80-07$ & 0.120 & 0.094 & 0.056 & 0.051 & 0.273 & 0.448 & 0.223 & 0.138 \\
\hline Ryanair & $97-07$ & 0.324 & 0.095 & 0.296 & 0.026 & 0.406 & 0.204 & 0.377 & 0.041 \\
\hline Siteserv & 04-07 & 0.334 & 0.291 & 0.201 & 0.103 & 0.349 & 0.456 & 0.361 & 0.101 \\
\hline Smurfit Kappa & $04-07$ & 0.579 & 0.620 & 0.517 & 0.034 & 0.181 & 0.252 & 0.166 & 0.072 \\
\hline South Wharf & $84-05$ & 0.112 & 0.055 & 0.006 & 0.053 & 0.648 & 0.666 & 0.603 & 0.422 \\
\hline Thirdforce & $98-07$ & 0.336 & 0.099 & 0.000 & 0.319 & 0.825 & 0.414 & 0.019 & 0.426 \\
\hline Total Produce & 04-07 & 0.135 & 0.173 & 0.070 & 0.065 & 0.132 & 0.101 & 0.116 & 0.017 \\
\hline Trinity Biotech & $98-07$ & 0.175 & 0.177 & 0.105 & 0.072 & 0.186 & 0.410 & 0.146 & 0.065 \\
\hline Unidare & $80-05$ & 0.168 & 0.134 & 0.112 & 0.051 & 0.276 & 0.356 & 0.225 & 0.152 \\
\hline United Drug & $89-07$ & 0.109 & 0.076 & 0.055 & 0.045 & 0.178 & 0.095 & 0.162 & 0.077 \\
\hline Waterford & $81-05$ & 0.395 & 0.275 & 0.274 & 0.021 & 0.328 & 0.425 & 0.431 & 0.287 \\
\hline
\end{tabular}

Table 2 presents the median and range of debt and debt maturity for 56 firms listed on the Irish Stock Exchange over the period from 1980 to 2007 . Book debt (BD) is total debt to total assets. Market debt (MD) is calculated as total debt to market value of assets, where market value of assets is equal to total book assets less the book value of equity plus market capitalisation. Debt maturity is either long- (LTD) or short-term debt (STD) to total assets, as indicated. The range is the difference between the maximum and minimum level or range of debt and debt maturity. Coverage is the number of years that the firm remains in the sample. 
across firms. For example, balance-sheet data is available for just two years for Bula, but much longer for firms such as Abbey (1982-2007) and Arnotts (1981-2003). The difference in sample coverage raises an important statistical issue, which, if not dealt with, will make comparsions in leverage ratios across time problematic. This is because since changes in sample composition will in itself cause changes in average (or median) debt, we need to isolate changes in debt over time related to changes in fundamental factors from changes in debt arising from changes in sample composition. To do so, first we estimate a series of two-way (time and firm) fixed-effects regressions that focus on 'within-firm' changes in corporate debt over time, which in turn are robust to changes in sample composition. Second, some Irish firms tend to be much more highly indebted than others. Some firms are debtfree (see Iona, for example), while others like C\&C (median book debt is 0.673 ) are much more highly indebebted. Strebulaev and Yang (2012) and Devos, Dhillon, Jagannathan and Krishnamurthy (2012) explore why a growing number of US firms remain debt-free. Interestingly, no firm appears to be excessively indebted, either on a book or market basis (i.e. book debt greater than 0.700 of total assets). Third, the debt of Irish firms tends to be predominantly long-term in nature. For example, the median long- (short-) term debt to assets is 0.291 (0.043) for Aer Lingus. Similar conclusions arise in the case of Arcon (0.292 versus 0.048), CRH (0.281 versus 0.052) and Kerry Group (0.297 versus 0.036 ). The average (median) long-term debt to total debt is $0.586(0.672)$. Almost without exception, where short-term debt dominates long-term debt, those firms typically have no long-term debt at all (see, for example, Abbey, Dragon Oil, and Qualceram). Fourth, the leverage and debt maturity ratios of firms exhibit significant variation over time. Consider Elan, whose book-debt range is 0.825 over the period 1989 to 2007 . These figures suggest that Irish debt ratios are not stable, and that Irish firms do not adhere to a target capital structure, at least in the sense that debt mean-reverts towards a specific target. In a survey of the chief financial officers of Irish firms listed on the Irish Stock Exchange, Kester and Robbins (2011) confirm that Irish corporate financing behaviour tends to adhere closely to the predictions of the pecking order (which does not imply a target capital structure), but not the static trade-off model (which does imply a target capital structure). Also, since most firms exhibit significant variation in debt ratios over time, these figures suggest that the observed aggregate changes in debt ratios (that we observe in Figures 1 and 2) are not caused by large changes across a few firms, but, more likely, by changes across many firms.

\section{Firm-Level Determinants of Debt}

As Mitton (2007) did, we follow Rajan and Zingales (1995) and Frank and Goyal (2003) in considering four fundamental factors that consistently arise in many studies, which examine the determinants of corporate debt, namely (a) firm-size (b) profitability (c) asset tangibility and (d) growth opportunities. ${ }^{5}$ All variables are sourced from Worldscope at the end of each year from 1981 to 2007, and are winsorised at the 1st and 99th percentiles. Following convention, and since our focus is very much on non-financial corporations, we exclude financial firms from our final sample. Firm-size is expected to be positively related to leverage, since larger firms have a lower probability of bankruptcy and lower (relative) costs of 
FIGURE I: DEBT RATIOS

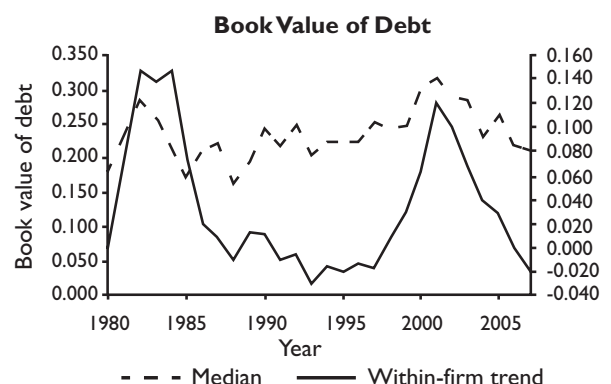

Book debt

\begin{tabular}{cccc}
\hline Average & Median & Std. dev. & Trend \\
\hline 0.248 & 0.240 & 0.175 & $0.12 / 2001$ \\
\hline
\end{tabular}

Total Debt to Common Equity

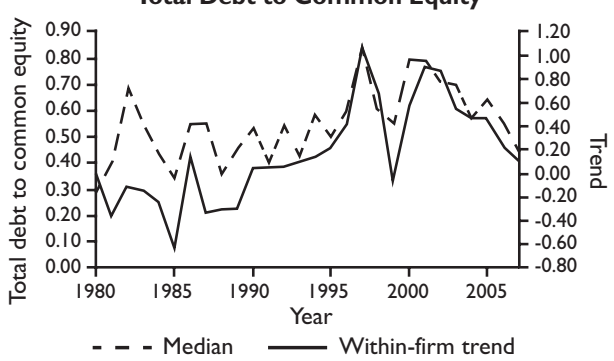

Total debt to common equity

\begin{tabular}{cccc}
\hline Average & Median & Std. dev. & Trend \\
\hline 1.335 & 0.565 & 2.558 & $1.05 / 1997$ \\
\hline
\end{tabular}

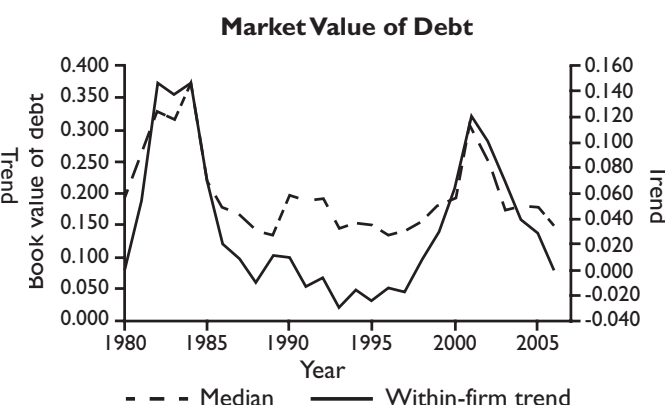

Market debt

\begin{tabular}{cccc}
\hline Average & Median & Std. dev. & Trend \\
\hline 0.202 & 0.179 & 0.160 & $0.12 / 2001$ \\
\hline
\end{tabular}

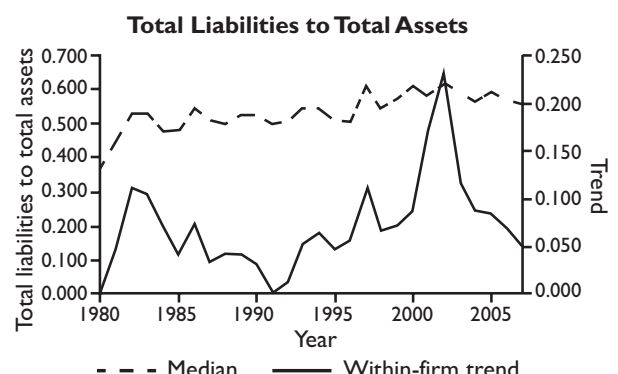

Total liabilities to total assets

\begin{tabular}{cccc}
\hline Average & Median & Std. dev. & Trend \\
\hline 0.542 & 0.549 & 0.309 & $0.23 / 2002$ \\
\hline
\end{tabular}

Figure I reports annual debt ratios for non-financial Irish firms from 1980 to 2007 . For each, we report the median and trend for each year from 1980 to 2007. Debt is measured as total debt to total assets (book debt); total debt to market value of assets (market debt), where market value of assets is calculated as total book assets less book value of equity plus market capitalisation; total debt to common equity, and total liabilities to total assets, as indicated. For each, report summary statistics are also reported, namely the average, median and standard deviation for each debt ratio. The final column of each table also reports the maximim value of the trend (and in which year) for each debt ratio over the sample period.

financial distress. Rajan and Zingales (1995), Frank and Goyal (2003) and Mitton (2007) show that larger firms use more leverage. Furthermore, smaller firms have lower debt capacities, and tend to use more equity than presecribed by the pecking order hypothesis (Lemmon and Zender, 2010). We measure firm-size using logs of sales, inflation-adjusted and in euros. ${ }^{6}$ The capital structure literature makes very different theoretical predictions with respect to the relationship between firmprofitability and leverage. On the one hand, the pecking order hypothesis of Myers and Majluf (1984) predicts a negative relationship between profitability and leverage, since profitable firms will utilise internal funds first, then external funds to fund their investment opportunities. ${ }^{7}$ In contrast, the static trade-off model predicts 
FIGURE 2: DEBT MATURITY RATIOS

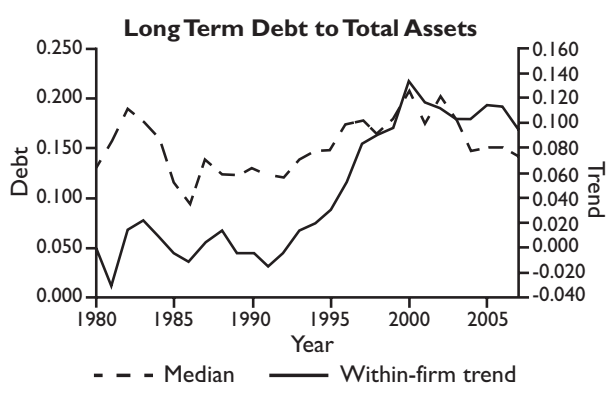

Long-term debt to total assets

\begin{tabular}{cccc}
\hline Average & Median & Std. dev. & Trend \\
\hline 0.176 & 0.149 & 0.162 & $0.133 / 2000$ \\
\hline
\end{tabular}

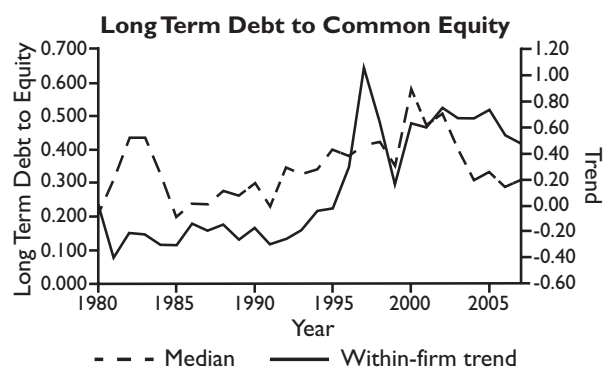

Long-term debt to common equity

\begin{tabular}{cccc}
\hline Average & Median & Std. dev. & Trend \\
\hline 0.933 & 0.339 & 2.004 & $1.050 / 1997$ \\
\hline
\end{tabular}

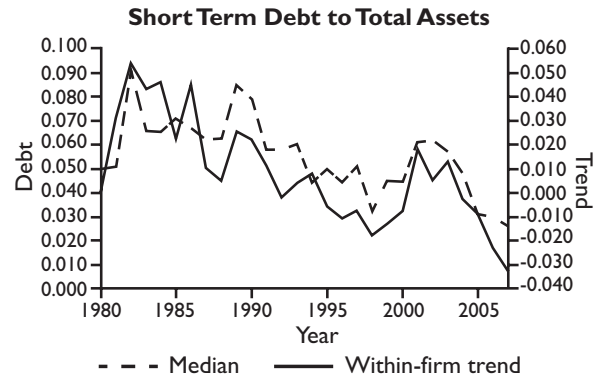

Short-term debt to total assets

\begin{tabular}{cccc}
\hline Average & Median & Std.dev. & Trend \\
\hline 0.070 & 0.050 & 0.076 & $0.091 / 1982$ \\
\hline
\end{tabular}

Total Liabilities to Total Assets

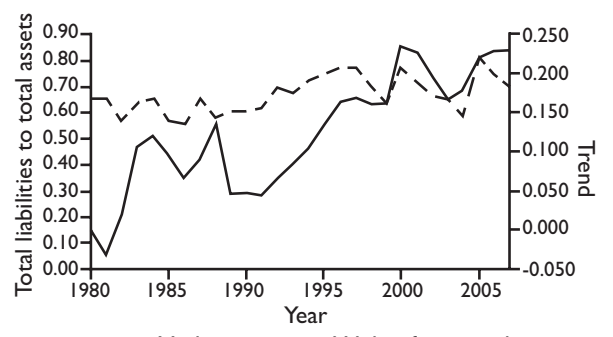

- - - Median W Within-firm trend

Long-term debt to total debt

\begin{tabular}{cccc}
\hline Average & Median & Std. dev. & Trend \\
\hline 0.586 & 0.672 & 0.334 & $0.234 / 2000$ \\
\hline
\end{tabular}

Figure 2 reports annual debt maturity ratios for non-financial Irish firms from 1980 to 2007. For each, we report the median and trend value annually. Debt maturity is measured as either long- or short-term debt to total assets, long-term debt to common equity, and long-term debt to total debt, as indicated. For each, report summary statistics are also reported, namely the average, median and standard deviation for each debt maturity ratio. The final column of each table also reports the maximim value of the trend (and in which year) for each debt ratio ratio over the sample period.

the opposite relationship, since profitable firms will use more leverage to fully utilise the gains from debt tax shields (Bradley, Jarrell, and Kim (1984)). Free-cash flow theories forwarded by Jensen (1986) and Stulz (1990) would suggest a positive relationship between profitability and debt, given the agency role-played by debt in reducing the agency costs associated with free-cash flow. In general, the empirical literature has found in favour of the predictions of pecking order hypothesis in this regard (Rajan and Zingales (1995); Frank and Goyal (2003); Mitton (2007)). We measure profitability as EBIT (Earnings Before Interest and Taxation) to total assets.

We measure tangibility as fixed assets to total assets. A large amount of empirical literature (Rajan and Zingales (1995); Frank and Goyal (2003)) has ratified the earlier predictions of Scott (1977), which suggests that firms with more tangible assets 
use more leverage. Our last remaining fundamental factor is growth opportunities. Following the reasoning of Myers (1977), profitable firms should use less leverage, since excessive leverage may force them to forego future profitable growth opportunities. While one could also argue that profitable firms are more likely to use debt, especially where equity markets are underdeveloped, thus implying a positive relationship, the empirical literature tends to find in favour of Myers's prediction (Rajan and Zingales (1995); Fama and French (2002); Mitton (2007)). We measure growth opportunities using Tobin's $q$, where Tobin's $q$ is measured as the book value of debt plus market capitalisation divided by the book value of assets. ${ }^{8} \mathrm{Next}$, and in addition to the firm-level factors just outlined, we explore the relationship between corporate debt and tax-related factors. We consider two separate tax-related factors, namely the average tax rate and non-debt tax shields. First, we measure the average tax rate paid by a firm as the ratio of income tax to pre-tax income. All else being equal, debt (interest-bearing) should increase with an increase in the average tax rate (see Graham (2003) for a review of the literature). Second, we account for nondebt tax shields. While the early literature suggests that non-debt tax shields and leverage may substitute for one another (DeAngelo and Masulis (1980)), the subsequent empirical findings suggest that they complement one another (see Bradley et al. (1984) and Mitton (2007) for empirical findings). We measure non-debt tax shields as depreciation, depletion and amortisation (DDA) to total assets.

\section{Country-level Determinants of Debt}

Next, we explore the possiblity that country-level factors may have impacted on the ability/incentive for corporations to use more debt financing over the specified period. We begin by assesing (and measuring) the availability of debt and equity financing in Ireland and elsewhere, namely by measuring credit and equity-market development over the sample period. We measure the development of Irish credit markets as the ratio of credit provided to the private sector to GDP. This data is sourced from the Central Bank of Ireland and the World Bank. We quantify the development of the Irish stock market as the ratio of the market capitalisation of listed companies to GDP. This data is sourced from an updated version of Beck, Demirguc-Kunt and Levine (2000). ${ }^{9}$ All else being equal, we would expect that stock-market development would lower debt usage in favour of equity financing. ${ }^{10}$

We then examine the possibility that Irish firms have sourced their debt financing from abroad. There is plenty of evidence to suggest that Irish firms sourced sizable amounts of debt financing from foreign markets. For example, in 2007 DCC sought $\$ 186$ million in a single visit to US debt markets. Henderson, Jegadeesh and Weisbach (2006), Gozzi, Levine and Schmukler (2009) and Gozzi, Levine, Peria and Schmukler (2012) highlight the greater use of international debt and equity markets by corporations. We explore this possibility using both firm- and country-level measures. At the firm- level, we create a series of cross-listing dummy variables, which are one if the firm cross-lists in the US (Level 1 or Level 2), or on the main or alternative (AIM) markets of the London Stock Exchange (London (Ordinary) and London (AIM): www. londonstockexchange.com). Cross-listing abroad is generally associated with greater access to debt and equity financing (Reese and Weisbach (2002); Lins, Strickland and Zenner (2005); Hail and Leuz (2009)). All information on Irish firms' cross-listing in 
the US is sourced from the Bank of New York (www.adrbnymellon.com), and crossreferenced with information from Deutsche Bank (www.adr.db.com), JP Morgan (www.adr.com), the New York Stock Exchange (www.nyse.com) and NASDAQ (www.nsadaq.com). To ensure that we correctly identify a firm's initial listing, we consult the historical records from the Bank of New York (since the currently available online records only refer to a firm's current, not initial, cross-listing). Furthermore, we cross-reference this data with data from Citibank (www.citiadr.com) who flag firms that have changed their cross-listing status by including a 'successor depositary receipt' data type for all firms. Using both databases, firms are classified as either Level 1 over-the-counter or Level 2 exchange-traded ADRs. Unlike Level 1 and Level 2 lists, Level 3 and Rule 144a firms are entitled to raise capital in the US. ${ }^{11}$ For inclusion in our sample, we require that firms have (financial) data available in both the pre- and post-listing periods. We source all listings in London directly from the London Stock Exchange. At the country level, we measure financial openness using the Chinn-Ito (2008) measure of financial openness. This index takes on higher values the more open the country is to cross-border capital transactions. The relationship between financial openness/cross-listing and debt is ambiguous, since financial openness/cross-listing is likely to increase the availability of both debt and equity financing. ${ }^{12}$ Finally, we examine how changes in creditor rights impact on debt financing. A priori, one might expect that changes in creditor rights and leverage move in the same direction, i.e. creditors are more likely to lend to firms when their legal standing in the event of bankruptcy is strong. However, Vig (2009) demonstrates that this is not necessarily the case. He shows that a securitisation reform that strengthened the rights of secured creditors in India was followed by a reduction in secured debt, total debt and debt maturity. In 1989, the protection afforded to creditors in Ireland was reduced from 2 to 1 (based on the creditor rights index of Djankov, McLiesh and Shleifer (2007)). In this paper, we examine how this change in creditor rights impacted on the use of debt financing by Irish firms.

\section{ANALYSIS}

\section{Preliminary Analysis}

We begin by depicting the time-series behaviour of debt for our sample of Irish firms over the full sample period. Figure 1 presents the debt ratios. In all figures, we present median debt and its within-firm trend, the latter included to alleviate concerns that the changes in the median (or average) value of debt ratios over time may simply reflect changes in sample composition..$^{13}$ We calculate the within-firm trend in debt (and other firm-level variables) by estimating regressions of the following form: FirmCharacteristic ${ }_{\text {it }}=\alpha+$ Firm $_{i}+$ Year $_{t}+\varepsilon_{i t}$, where FirmCharacteristic ${ }_{i t}$ is the firm-level variable of interest (e.g. book debt) for firm i in year $t$, Firm $_{i}$ is a full set of firm-fixed effects, and Year $_{t}$ is a full set of year-fixed effects. The reference year is 1980. The inclusion of firm-fixed-effects controls for changes in sample composition, and therefore the coefficients on the year dummies, represents the average incremental change in firm-characteristics (e.g. book debt) attributable to each year. The within-firm trend depicted in Figure 1 (and subsequent figures) is the estimated 
year coefficients on the set of year dummies from estimating Eq. (1). In Figures 1 and 2, we present the average, median and standard deviation of each debt/debt maturity ratio in the tables underneath. In the last column of each table, we present the year in which debt/debt maturity peaked (using the trend).

Figure 1 displays the median and within-firm trend of Irish debt ratios (book and market debt) over the period from 1980 to 2007. We supplement these figures with two additional measures of debt, namely total debt to total (common) equity, and total liabilitites to total assets. These figures suggest the following: non-financial Irish firms experienced an increase in debt ratios in the region of 12 percentage points (using the within-firm trend data), over the period from 1980 to 2001. Subsequent to 2001, Irish debt ratios dropped back to just under 1980 levels (again using the withinfirm trend data). ${ }^{14}$ Book (market) debt for the median firm peaked at $0.32(0.30)$ in 2001. Since 2001, book (market) debt for the median firms has fallen to 0.21 (0.14) by 2007 (see top row of Figure 1), corresponding to a within-firm decline of 14 percentage points. Debt to equity peaks in 1997 (Trend is 1.05), while total liabilities to total assets peaks in 2002 (Trend is 0.23 ) (see bottom row of Figure 1). The fall in book and market debt (and debt to equity and total liabilities to total assets) since 2001 is the result of both decreases in debt (numerator) and increases in size (the denominator). For example, from 2001 to 2005, net debt issuance is negative, but positive thereafter (this figure is unreported). The net effect (of the increase to 2001 and the fall-off thereafter) is that, based on the trend data, the median Irish non-financial firm is less indebted (relative to assets) at the end of our sample period than at the begining. ${ }^{15}$ Interestingly, the debt to equity ratio suggests that in the period from 1996 to 1999, the debt to equity ratio continuted to fall even given increased debt financing. Hence, in this period, equity issuance outstripped debt issuance for Irish firms.

In Figure 2, we examine the maturity structure of Irish debt. We outline the median and within-firm trend for long- and short-term debt to total assets (see top row of Figure 2), long-term debt to common equity, and finally, long-term debt to total debt (see bottom row of Figure 2). In contrast to the emerging market firms examined by Mitton (2007) and the US firms examined by Custodio, Ferreira and Laureano (2012), the increased use of debt by Irish firms in recent times has tended to be predominatly long-term, which has increased relative to both short-term debt (see long-term debt to total debt) and common equity (see long-term debt to common equity). For example, between 1980 and 2007, median long-term debt to total debt (long-term debt to common equity) increased from $0.66(0.21)$ to 0.80 (0.39), peaking at $0.87(0.68)$ in 2005 (2000). The corresponding within-firm trend suggests that over the entire sample period, long-term debt to total debt increased by 28 percentage points, and long-term debt to common equity increased by 51 percentage points, after peaking at 81 percentage points in 2002. In contrast, relative to common equity, short-term debt has declined by just under 40 percentage points, between 1980 and 2007. In the next section, we examine the potential causes of the trends in leverage witnessed over the course of the sample period.

\section{Regression Analysis}

We begin by estimating a series of firm-fixed effects regressions that relate our firmlevel factors to debt ratios over the period from 1980 to 2007. Before we do so, first 
consider Figures 3 and 4 . Figure 3 depicts the time-series behaviour of the firmlevel determinants (tangibility, profitability, size, growth opportunities, tax rate and non-debt tax shields) of debt, while Table 4 depicts the country-level determinants (stock-market development, credit-market development, financial openness and creditor rights). In the period to 2001, all six firm-level determinants appeared to move in the direction that would imply an increase in debt financing, i.e. the asset base became more tangible (between 1997 and 2001, median asset tangibility increased from 0.471 to 0.586 ); firms became less profitable (between 1997 and 2001, median profitability fell from 0.136 to 0.097); larger (with few exceptions, firmsize increased throughout the sample period); and had fewer growth opportunities (between 1997 and 2002, growth opportunities fell from 1.50 to 1.16). Furthermore, both tax-related variables also moved in the direction that would imply greater use of debt, namely, a decrease in the tax rate, and an increase in non-debt tax shields. Finally, with the exception of firm-size and the tax rate, each of the four other firmlevel leverage determinants moved in the direction that would suggest less debt financing in the post-2001 period, that is, the asset base became less tangible, firms

FIGURE 3: FIRM-LEVEL VARIABLES
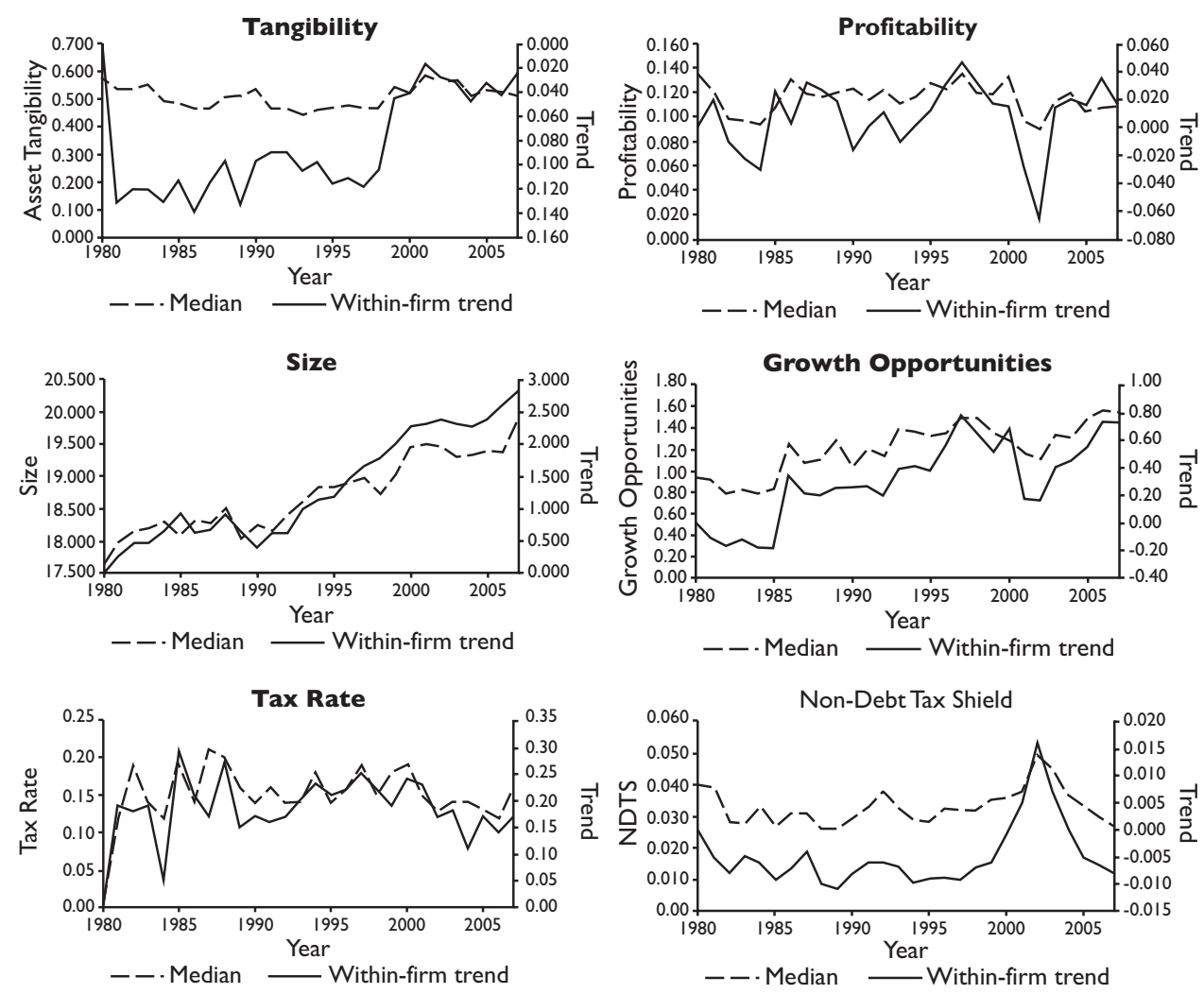

Figure 3 reports annual firm-level fundamental factors for non-financial Irish firms from 1980 to 2007. For each, we report the median and trend value annually. Annual values are reported for tangibility, profitability, size, growth opportunities, tax rate and non-debt tax shields. 
FIGURE 4: COUNTRY-LEVEL VARIABLES
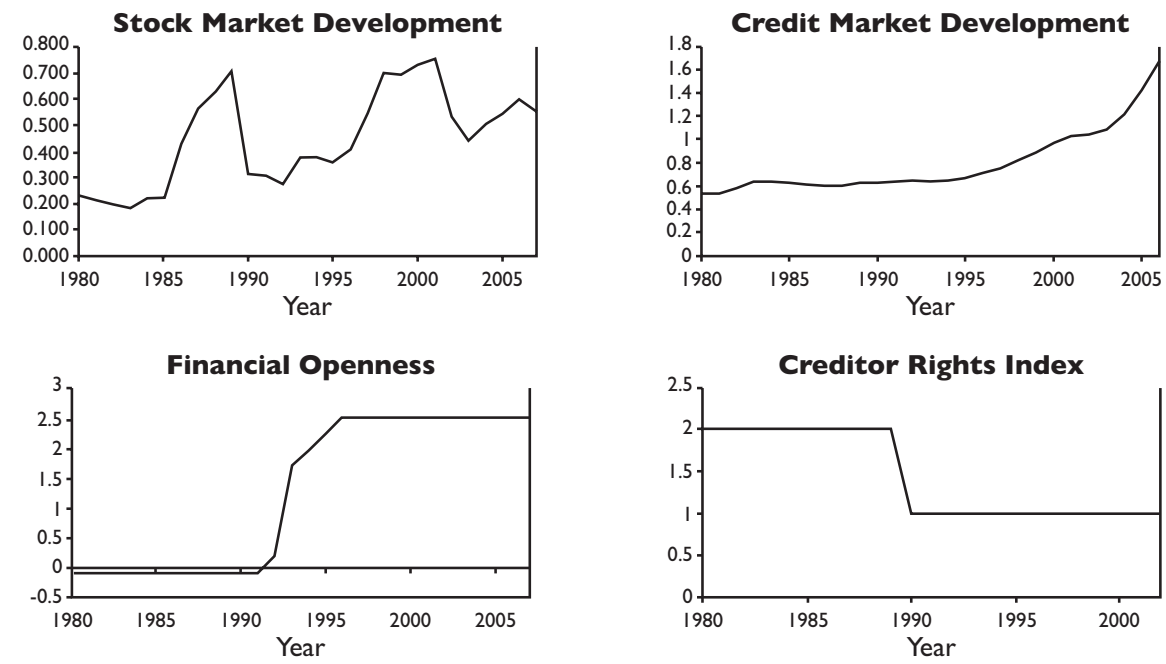

Figure 4 reports annual country-level fundamental factors for Ireland from 1980 to 2007. Stock-market development is defined as domestic market capitalisation to gross domestic product (GDP) and Bank-sector development is deposit money bank assets to GDP. Creditor rights is a measure of creditor rights taken from Djankov et al. (2007). Financial openness is measured using the Chinn-Ito (2008) measure of financial openness.

became more profitable, with increased growth opportunities, while non-debt tax shields also fell in value.

The country-level determinants are depicted in Figure 4. The evolution of stockmarket development over time would appear to depict a positive relationship with debt. The Irish stock market tended to develop from 1991 to 2001, the period coinciding with the greater use of debt and equity financing by Irish firms (see Figure 1 ), but in line with the dot-com bubble, stock-market capitalisations tend to fall for three to four years post-2001. Credit markets developed throughout the period. Ireland's measure of financial openness increased in the period that pre-dates the increased use of debt financing by Irish firms. In the sample period, creditor rights experience a one-off decrease from 2 in 1989 to 1 in 1990.

Regression results are presented in Table 3 where the dependent variable is book debt. First, we examine how trends in the firm-level fundamentals are associated with trends in long-term trends in corporate debt financing (see Panel A of Table 3). Column 1 indicates that higher tangibility is associated with higher debt ratios although the finding is not statistically significant. Column 2 suggests that higher profitability is associated with lower levels of debt, while in column 3 we show that larger firm-size is indicative of higher debt ratios. The former finding is in line with the predictions of the pecking order hypothesis, while the latter validates the predictions of the trade-off model. These coefficients are of the expected sign, statistically significant, and in line with previous literature. Finally, in column 4, we find no significant relationship between growth opportunities and debt levels. The same two variables (profitability and size) remain statistically significant when all variables are included in the regression together. Next, we distinguish between firms 
Which Factors Determine the Capital Structure of Non-Financial Publicly Traded Irish Firms?

TABLE 3: FIRM-FUNDAMENTALS AND DEBT RATIOS

\begin{tabular}{|c|c|c|c|c|c|c|c|c|c|}
\hline \multirow[t]{2}{*}{ Panel A } & \multicolumn{4}{|c|}{ Firm-fundamentals } & \multicolumn{2}{|c|}{ Cross-listing } & \multirow{2}{*}{$\begin{array}{l}\text { Tax } \\
\text { (7) }\end{array}$} & \multicolumn{2}{|c|}{ All } \\
\hline & (I) & (2) & (3) & (4) & $(5)$ & (6) & & $(8)$ & $(9)$ \\
\hline Tangibility & $\begin{array}{l}0.077 \\
(1.33)\end{array}$ & & & & & $\begin{array}{l}0.067 \\
(1.24)\end{array}$ & & $\begin{array}{l}0.074 \\
(1.28)\end{array}$ & $\begin{array}{l}0.088 \\
(1.63)\end{array}$ \\
\hline Profitability & & $\begin{array}{l}-0.20 * * * \\
(3.11)\end{array}$ & & & & $\begin{array}{c}-0.23 * * * \\
(3.82)\end{array}$ & & $\begin{array}{c}-0.236 * * * \\
(3.91)\end{array}$ & $\begin{array}{c}-0.254 * * * \\
(3.66)\end{array}$ \\
\hline Size & & & $\begin{array}{c}0.025^{* * * *} \\
(3.13)\end{array}$ & & & $\begin{array}{c}0.034 * * * \\
(4.25)\end{array}$ & & $\begin{array}{c}0.034 * * * \\
(4.25)\end{array}$ & $\begin{array}{c}0.039 * * * \\
(5.90)\end{array}$ \\
\hline $\begin{array}{l}\text { Growth } \\
\text { opportunities }\end{array}$ & & & & $\begin{array}{l}0.010 \\
(0.08)\end{array}$ & & $\begin{array}{l}0.008 \\
(1.05)\end{array}$ & & $\begin{array}{l}0.008 \\
(0.90)\end{array}$ & $\begin{array}{l}0.008 \\
(0.87)\end{array}$ \\
\hline Level I & & & & & $\begin{array}{l}0.019 \\
(0.68)\end{array}$ & $\begin{array}{l}0.011 \\
(0.42)\end{array}$ & & $\begin{array}{l}0.013 \\
(0.15)\end{array}$ & $\begin{array}{l}0.016 \\
(0.64)\end{array}$ \\
\hline Level 2 & & & & & $\begin{array}{l}-0.032 \\
(0.73)\end{array}$ & $\begin{array}{l}-0.033 \\
(0.77)\end{array}$ & & $\begin{array}{l}-0.037 \\
(0.66)\end{array}$ & $\begin{array}{l}-0.031 \\
(0.79)\end{array}$ \\
\hline London (ordinary) & & & & & $\begin{array}{l}-0.004 \\
(0.17)\end{array}$ & $\begin{array}{l}-0.034 \\
(1.48)\end{array}$ & & $\begin{array}{r}-0.033 \\
(1.40)\end{array}$ & $\begin{array}{l}-0.019 \\
(0.79)\end{array}$ \\
\hline London (AIM) & & & & & $\begin{array}{l}-0.062 \\
(1.38)\end{array}$ & $\begin{array}{l}-0.008 \\
(0.20)\end{array}$ & & $\begin{array}{l}-0.005 \\
(0.12)\end{array}$ & $\begin{array}{l}0.001 \\
(0.01)\end{array}$ \\
\hline Tax shield & & & & & & & $\begin{array}{l}0.028 \\
(1.12)\end{array}$ & $\begin{array}{l}0.040 \\
(1.61)\end{array}$ & $\begin{array}{l}0.046 \\
(1.62)\end{array}$ \\
\hline NDTS & & & & & & & $\begin{array}{l}0.309 \\
(0.81)\end{array}$ & $\begin{array}{l}0.043 \\
(0.10)\end{array}$ & $\begin{array}{l}0.232 \\
(0.61)\end{array}$ \\
\hline \# Obs & 763 & 763 & 763 & 763 & 763 & 763 & 763 & 763 & 763 \\
\hline R-squared & 0.054 & 0.044 & 0.121 & 0.030 & 0.031 & 0.229 & 0.033 & 0.225 & 0.217 \\
\hline Year dummies & Yes & Yes & Yes & Yes & Yes & Yes & Yes & Yes & No \\
\hline \multirow[t]{2}{*}{ Panel B } & \multicolumn{9}{|c|}{ Estimates of economic significance (\%) - total period } \\
\hline & $(1)$ & $(2)$ & (3) & $(4)$ & (5) & (6) & $(7)$ & $(8)$ & $(9)$ \\
\hline Tangibility & $(0.20)$ & & & & & $(0.16)$ & & $(0.18)$ & $(0.2 I)$ \\
\hline Profitability & & $(0.34)$ & & & & $(0.39)$ & & $(0.40)$ & $(0.43)$ \\
\hline Size & & & 7.05 & & & 9.59 & & 9.59 & 11.00 \\
\hline $\begin{array}{l}\text { Growth } \\
\text { opportunities }\end{array}$ & & & & 0.73 & & 0.58 & & 0.58 & 0.58 \\
\hline Level I & & & & & 1.90 & 1.10 & & 1.30 & 1.60 \\
\hline Level 2 & & & & & $(3.20)$ & $(3.30)$ & & $(3.70)$ & $(3.10)$ \\
\hline London (ordinary) & & & & & $(0.40)$ & $(3.40)$ & & $(3.30)$ & $(1.90)$ \\
\hline London (AIM) & & & & & $(6.20)$ & $(0.80)$ & & $(0.50)$ & 0.10 \\
\hline Tax shield & & & & & & & 0.48 & 0.68 & 0.78 \\
\hline NDTS & & & & & & & $(0.25)$ & $(0.03)$ & $(0.19)$ \\
\hline
\end{tabular}

Sum of statistically significant coefficients - economic significance (\%)

(0.34) $\quad 7.05$

9.20

9.19

10.57

(Continued) 
TABLE 3 (CONTINUED)

\begin{tabular}{|c|c|c|c|c|c|c|c|c|c|}
\hline \multirow[t]{2}{*}{ Panel C } & \multicolumn{9}{|c|}{ Estimates of economic significance (\%) - |980-200 I } \\
\hline & ( & (2) & (3) & $(4)$ & (5) & $(6)$ & (7) & $(8)$ & (9) \\
\hline Tangibility & $(0.13)$ & & & & & $(0.11)$ & & $(0.13)$ & $(0.15)$ \\
\hline Profitability & & 0.56 & & & & 0.64 & & 0.66 & 0.71 \\
\hline Size & & & 5.78 & & & 7.85 & & 7.85 & 9.00 \\
\hline $\begin{array}{l}\text { Growth } \\
\text { opportunities }\end{array}$ & & & & 0.18 & & 0.14 & & 0.14 & 0.14 \\
\hline Level I & & & & & 1.90 & 1.10 & & 1.30 & 1.60 \\
\hline Level 2 & & & & & (3.20) & $(3.30)$ & & $(3.70)$ & $(3.10)$ \\
\hline London (ordinary) & & & & & $(0.40)$ & $(3.40)$ & & $(3.30)$ & $(1.90)$ \\
\hline London (AIM) & & & & & $(6.20)$ & $(0.80)$ & & $(0.50)$ & 0.10 \\
\hline Tax Shield & & & & & & & 0.64 & 0.92 & 1.06 \\
\hline \multirow[t]{3}{*}{ NDTS } & & & & & & & 0.15 & 0.02 & 0.12 \\
\hline & \multicolumn{9}{|c|}{ Sum of statistically significant coefficients - economic significance (\%) - |980-200। } \\
\hline & & 0.56 & 5.78 & & & 8.49 & & 8.51 & 9.71 \\
\hline \multirow[t]{2}{*}{ Panel D } & \multicolumn{9}{|c|}{ Estimates of economic significance (\%) - 200 I-2007 } \\
\hline & $(1)$ & $(2)$ & $(3)$ & $(4)$ & $(5)$ & $(6)$ & $(7)$ & $(8)$ & $(9)$ \\
\hline Tangibility & $(0.05)$ & & & & & $(0.05)$ & & $(0.05)$ & $(0.06)$ \\
\hline Profitability & & $(0.90)$ & & & & $(1.04)$ & & $(1.06)$ & $(1.14)$ \\
\hline Size & & & 1.28 & & & 1.73 & & 1.73 & 1.99 \\
\hline $\begin{array}{l}\text { Growth } \\
\text { opportunities }\end{array}$ & & & & 0.55 & & 0.44 & & 0.44 & 0.44 \\
\hline Level I & & & & & 1.90 & 1.10 & & 1.30 & 1.60 \\
\hline Level 2 & & & & & (3.20) & (3.30) & & $(3.70)$ & $(3.10)$ \\
\hline London (ordinary) & & & & & $(0.40)$ & $(3.40)$ & & $(3.30)$ & $(1.90)$ \\
\hline London (AIM) & & & & & $(6.20)$ & $(0.80)$ & & $(0.50)$ & 0.10 \\
\hline Tax shield & & & & & & & $(0.17)$ & $(0.24)$ & $(0.28)$ \\
\hline NDTS & & & & & & & $(0.40)$ & $(0.06)$ & $(0.30)$ \\
\hline
\end{tabular}

Sum of statistically significant coefficients - economic significance (\%) - 200I-2007

(0.90) $\quad 1.28$

0.69

0.67

0.85

Table 3 reports firm-fixed-effect estimates of the impact of firm-level fundamentals, international cross-listing and tax-related factors on debt ratios of Irish firms from 1980 to 2007. Debt is total debt to total assets (book debt). All other firm-level variables are defined in the main text. All firm-level variables are sourced from Worldscope. Level I and Level 2 are dummy variables representing whether a firm is cross-listed in the US either as a Level I over-the-counter issue or as an exchange-traded Level 2/3 ADR. London (ordinary) and London (AIM) are dummy variables, which are I if the firms are cross-listed in London as either an ordinary or AIM listing. All information on US cross-listed firms is sourced from the Bank of New York, and is cross-referenced with information from Citibank, JP Morgan Chase, the New York Stock Exchange and Nasdaq. Information on UK cross-listings is sourced from the London Stock Exchange. A full set of year (except for column 9) and firm-fixed effects are included, but not reported. The t-statistics are calculated using bootstrapped standard errors ( 200 replications). The standard errors are adjusted for clustering at the firm-level. The R-Squared is the overall R-Squared. \# Obs is the number of firm/year observations. $* * *, * * *$ Denotes significance at the $1 \%, 5 \%$, and $10 \%$ level, respectively. In the remaining 
rows of Table I, the economic significance of each of the firm-fundamentals, cross-listing and tax-related factors are calculated. Estimates of economic significance for three periods are presented, namely the total period (19802007), from 1980 to $200 \mathrm{I}$, and from $200 \mathrm{I}$ to 2007 . Bold indicates that the estimates are also statistically significant at conventional levels.

that cross-list and firms that do not. This is done by introducing a dummy variable that takes on the value of one if the firm-cross-lists of the specified type, either in the US or the UK, and zero otherwise. When we introduce the possibility through the introduction of our dummy cross-listing variables that Irish firms have sourced their debt financing from foreign markets, the same two variables (size and profitability) are found to be statistically significant. The results also indicate that firms that cross-list in the US as Level 2 ADRs, or in either the main or alternative markets of the London Stock Exchange, have lower associated debt ratios. These findings are not, however, statistically significant. We next examine the effects of two taxrelated factors. First, the tax shield. The coefficient is positive, as would be expected, although not statistically significant. We next include non-debt tax shields. Once again, the coefficient is positive but statistically insignificant.

Finally, we consider the economic significance of our results to assess how debt ratios would be expected to change as a result of average changes in the firm-level fundamentals. The estimates of economic significance are calculated by multiplying the regression coefficient by the change in the within-firm trend from 1980 to 2007 for each variable (see Panel B of Table 3). The average change in firm-level tangibility from 1980 to 2007 was -0.026 . Hence the regression coefficient on tangibility of 0.077 would indicate that the decrease in asset tangibility would be associated with an average debt ratio decrease of 0.20 percentage points (i.e. $\left.\left(-0.026^{*} 0.077\right)^{*} 100\right)$. We calculate the same estimates of economic significance for profitability, size and growth. The average change in firm-level profitability is 0.017 while the regression coefficient is -0.020 . This indicates that the increase in profitability is associated with a decrease of average debt ratio of 0.34 percentage points (i.e. $\left.\left(0.017^{*}-0.020\right)^{*} 100\right)$. The results are statistically significant at the $1 \%$ level, and of the expected sign, and suggest that profitable firms tend to turn to internal financing initially. However, while the coefficient estimate on the profitability variable is statistically significant, from an economic viewpoint it is much less significant.

When considering the economic significance of the size of the firm, the regression coefficient of 0.025 and the increase of the within-firm trend of 2.82 indicate that the increase in size is associated with an increase in the average debt ratio of 7.05 percentage points. The results are again significant at the $1 \%$ level. We calculate the same estimate of economic significance for growth opportunities but the results are not statistically significant. The estimates of the two statistically significant variables increase when we distinguish between firms that cross-list and those that do not, and when we include all the control variables. At the bottom of Table 3, we outline the sum of the statistically significant estimates of economic significance. Using the coefficient estimates from column 9 (where time (year) fixed-effects are excluded), the statistically significant variables imply an increase in book debt over the full sample period in the region of 10.57 percentage points (i.e. Profitability $(-0.43)+$ Size $(11.00)=10.57)$. In other words, all of the increase in corporate debt is attributable to firm-size. 
We further analyse the economic significance of our variables by dividing our sample into two sub-sample periods, namely 1980-2001 (see Panel C of Table 3) and 2001-2007 (see Panel D of Table 3). Once again we find no statistically significant results when we consider firm-tangibility and growth opportunities. However, when we consider profitability, an interesting picture emerges. For our earlier subsample (1980-2001), the estimate of economic significance is 0.56 . This indicates that the change in the within-firm profitability trend between 1980 and 2001 is associated with an increase in the average debt ratio of 0.56 percentage points. When examining the later sub-sample, we find the opposite. The estimate of economic significance of profitability from 2001 to 2007 is - 0.90 , indicating that the change in the within-firm profitability is associated with a decrease in the average debt ratio of 0.90 percentage points. This figure becomes more negative when we include all our control variables in the regression (-1.14 in column 9). This is not surprising, since the behaviour of firm-profitability over time, depicted in Figure 3, suggests that profitability moved in the direction pre- (post-) 2001, which would imply more (less) debt financing pre- (post-) 2001. Finally, we consider what happens to size over our two sub-sample periods. Our estimate of economic significance is positive and significant across sub-periods. However, the coefficients on the estimates are very different. When we look at the earlier sample period, we find that an increase in the within-firm trend is associated with an increase in the average debt ratio of 5.78 percentage points. The estimate of economic significance for the latter sample period indicates that an increase in the within-firm trend is associated with an increase in the average debt ratio of just 1.28 percentage points (or 1.99 percentage points when all variables are included and year-fixed-effects excluded). In effect, neither profitability nor size can account for the decreased use of debt financing of Irish firms from 2001. Their combined effect implies an increase in debt post-2001 in the region of just 0.85 percentage points (i.e. $-1.14+1.99$ ).

We continue our analysis by estimating the same regression, except that the dependent variable is market debt. Our results are presented in Table 4. Column 1 (see Panel A of Table 4) shows that higher asset tangibility is associated with higher debt ratios. The coefficient is positive, but unlike the case where debt is book debt, significant at the $1 \%$ level. This is in line with empirical findings that show firms with more tangible assets can use more leverage. In column 2 we again find a negative relationship between profitability and debt ratios. The negative coefficient implies that more profitable firms use less debt. The coefficient on size is again positive and statistically significant, indicating that larger firm-size is associated with higher debt ratios. This is consistent with the findings of many previous studies (Rajan and Zingales (1995); Mitton (2007)). The coefficient on growth opportunities is negative and significant, implying that firms with lower market-to-book ratios have higher debt ratios.

Again we consider the economic significance of our results. The average change in firm-level tangibility from 1980 to 2007 was -0.024 , while the regression coefficient on tangibility of 0.155 indicated that the decrease in asset tangibility would be associated with an average debt-ratio decrease of 0.37 percentage points (i.e. $(-0.024 * 0.155) * 100)$ (see Panel B of Table 4$)$. The results are positive and significant at the $1 \%$ level. We calculate the same estimates of economic significance for 
Which Factors Determine the Capital Structure of Non-Financial Publicly Traded Irish Firms?

TABLE 4: FIRM-FUNDAMENTALS AND DEBT RATIOS

\begin{tabular}{|c|c|c|c|c|c|c|c|c|c|}
\hline \multirow[t]{2}{*}{ Panel A } & \multicolumn{4}{|c|}{ Firm-fundamentals } & \multicolumn{2}{|c|}{ Cross-listing } & \multirow{2}{*}{$\begin{array}{l}\operatorname{Tax} \\
(7)\end{array}$} & \multicolumn{2}{|c|}{ All } \\
\hline & (I) & $(2)$ & (3) & (4) & (5) & (6) & & (8) & (9) \\
\hline Tangibility & $\begin{array}{l}0.155^{* * * *} \\
(3.37)\end{array}$ & & & & & $\begin{array}{l}0.070 \\
(1.43)\end{array}$ & & $\begin{array}{l}0.080 \\
(1.47)\end{array}$ & $\begin{array}{l}0.086^{*} \\
(1.86)\end{array}$ \\
\hline Profitability & & $\begin{array}{c}-0.14 * * * \\
(3.11)\end{array}$ & & & & $\begin{array}{l}-0.20 * * * \\
(4.10)\end{array}$ & & $\begin{array}{c}-0.216 * * * \\
(3.93)\end{array}$ & $\begin{array}{c}-0.243 * * * \\
(4.78)\end{array}$ \\
\hline Size & & & $\begin{array}{c}0.032 * * * \\
(5.33)\end{array}$ & & & $\begin{array}{c}0.025 * * * * \\
(3.57)\end{array}$ & & $\begin{array}{c}0.026 * * * \\
(3.63)\end{array}$ & $\begin{array}{c}0.023 * * * \\
(4.44)\end{array}$ \\
\hline $\begin{array}{l}\text { Growth } \\
\text { opportunities }\end{array}$ & & & & $\begin{array}{c}-0.05 * * * * \\
(7.42)\end{array}$ & & $\begin{array}{c}-0.04^{* * * *} \\
(6.00)\end{array}$ & & $\begin{array}{c}-0.042 * * * \\
(5.75)\end{array}$ & $\begin{array}{c}-0.048^{* * *} \\
(6.57)\end{array}$ \\
\hline Level I & & & & & $\begin{array}{r}-0.035 \\
(1.09)\end{array}$ & $\begin{array}{l}-0.040 \\
(1.48)\end{array}$ & & $\begin{array}{l}-0.037 \\
(1.33)\end{array}$ & $\begin{array}{l}-0.035 \\
(1.42)\end{array}$ \\
\hline Level 2 & & & & & $\begin{array}{l}-0.031 \\
(0.67)\end{array}$ & $\begin{array}{l}-0.022 \\
(0.56)\end{array}$ & & $\begin{array}{l}-0.024 \\
(0.60)\end{array}$ & $\begin{array}{l}-0.050 \\
(1.55)\end{array}$ \\
\hline $\begin{array}{l}\text { London } \\
\text { (ordinary) }\end{array}$ & & & & & $\begin{array}{l}0.003 \\
(0.14)\end{array}$ & $\begin{array}{l}-0.010 \\
(0.43)\end{array}$ & & $\begin{array}{l}-0.010 \\
(0.40)\end{array}$ & $\begin{array}{l}0.005 \\
(0.22)\end{array}$ \\
\hline London (AIM) & & & & & $\begin{array}{l}0.043 \\
(1.43)\end{array}$ & $\begin{array}{l}0.050 \\
(1.47)\end{array}$ & & $\begin{array}{l}0.058 \\
(1.53)\end{array}$ & $\begin{array}{l}0.042 \\
(1.14)\end{array}$ \\
\hline Tax shield & & & & & & & $\begin{array}{l}0.034 \\
(1.43)\end{array}$ & $\begin{array}{l}0.048 * \\
(1.86)\end{array}$ & $\begin{array}{c}0.053^{* * *} \\
(2.12)\end{array}$ \\
\hline NDTS & & & & & & & $\begin{array}{l}-0.061 \\
(0.20)\end{array}$ & $\begin{array}{l}-0.248 \\
(0.79)\end{array}$ & $\begin{array}{l}0.160 \\
(0.49)\end{array}$ \\
\hline \# Obs & 763 & 763 & 763 & 763 & 763 & 763 & 763 & 763 & 763 \\
\hline R-squared & 0.110 & 0.069 & 0.126 & 0.202 & 0.057 & 0.305 & 0.067 & 0.292 & 0.261 \\
\hline Year dummies & Yes & Yes & Yes & Yes & Yes & Yes & Yes & Yes & No \\
\hline
\end{tabular}

Panel B Estimates of economic significance (\%) - total period

$\begin{array}{llllllll}(1) & (2) & \text { (3) } & \text { (4) } & \text { (5) } & \text { (6) } & \text { (7) } & \text { (8) }\end{array}$

\begin{tabular}{|c|c|c|c|c|c|c|c|c|c|}
\hline & 1.7 & (2) & (D) & (1) & (D) & (0) & (17) & (D) & (1) \\
\hline Tangibility & $(0.37)$ & & & & & $(0.17)$ & & $(0.19)$ & $(0.2 I)$ \\
\hline Profitability & & $(0.24)$ & & & & $(0.34)$ & & $(0.37)$ & $(0.4 I)$ \\
\hline Size & & & 9.02 & & & 7.05 & & 7.33 & 6.49 \\
\hline $\begin{array}{l}\text { Growth } \\
\text { opportunities }\end{array}$ & & & & (3.65) & & $(2.92)$ & & (3.07) & (3.50) \\
\hline Level I & & & & & $(3.50)$ & $(4.00)$ & & (3.70) & (3.70) \\
\hline Level 2 & & & & & $(3.10)$ & $(2.20)$ & & (2.40) & (2.40) \\
\hline $\begin{array}{l}\text { London } \\
\text { (ordinary) }\end{array}$ & & & & & 0.30 & $(1.00)$ & & $(1.00)$ & $(1.00)$ \\
\hline London (AIM) & & & & & 4.30 & 5.00 & & 5.80 & 5.80 \\
\hline Tax shield & & & & & & & 0.58 & 0.82 & 0.90 \\
\hline NDTS & & & & & & & 0.05 & 0.20 & $(0.13)$ \\
\hline
\end{tabular}

Sum of statistically significant coefficients - economic significance (\%)

\begin{tabular}{ccccccc}
$(0.37)$ & $(0.24)$ & 9.02 & $(3.65)$ & 3.79 & 4.71 & 3.27 \\
\hline & & & & & (Continued)
\end{tabular}


TABLE 4 (CONTINUED)

\begin{tabular}{|c|c|c|c|c|c|c|c|c|c|}
\hline \multirow[t]{2}{*}{ Panel C } & \multicolumn{9}{|c|}{ Estimates of economic significance (\%) - |980-200| } \\
\hline & ( & $(2)$ & (3) & (4) & (5) & $(6)$ & (7) & $(8)$ & (9) \\
\hline Tangibility & $(0.26)$ & & & & & $(0.12)$ & & $(0.14)$ & $(0.15)$ \\
\hline Profitability & & 0.39 & & & & 0.56 & & 0.60 & 0.68 \\
\hline Size & & & 7.39 & & & 5.78 & & 6.01 & 5.31 \\
\hline $\begin{array}{l}\text { Growth } \\
\text { opportunities }\end{array}$ & & & & $(0.90)$ & & $(0.72)$ & & $(0.76)$ & $(0.86)$ \\
\hline Level I & & & & & $(3.50)$ & $(4.00)$ & & $(3.70)$ & $(3.70)$ \\
\hline Level 2 & & & & & $(3.10)$ & $(2.20)$ & & $(2.40)$ & $(2.40)$ \\
\hline $\begin{array}{l}\text { London } \\
\text { (ordinary) }\end{array}$ & & & & & 0.30 & $(1.00)$ & & $(1.00)$ & $(1.00)$ \\
\hline London (AIM) & & & & & 4.30 & 5.00 & & 5.80 & 5.80 \\
\hline Tax shield & & & & & & & 0.78 & 1.10 & 1.22 \\
\hline \multirow[t]{3}{*}{ NDTS } & & & & & & & $(0.03)$ & $(0.12)$ & 0.08 \\
\hline & \multicolumn{9}{|c|}{ Sum of statistically significant coefficients - economic significance (\%) - |980-200। } \\
\hline & $(0.26)$ & 0.39 & 7.39 & $(0.90)$ & & 5.62 & & 6.95 & 6.20 \\
\hline \multirow[t]{2}{*}{ Panel D } & \multicolumn{9}{|c|}{ Estimates of economic significance (\%) - 200 I-2007 } \\
\hline & ( & $(2)$ & (3) & (4) & (5) & $(6)$ & (7) & (8) & $(9)$ \\
\hline Tangibility & $(0.11)$ & & & & & $(0.05)$ & & $(0.06)$ & $(0.06)$ \\
\hline Profitability & & $(0.63)$ & & & & $(0.90)$ & & $(0.97)$ & $(1.09)$ \\
\hline Size & & & 1.63 & & & 1.28 & & 1.33 & 1.17 \\
\hline $\begin{array}{l}\text { Growth } \\
\text { opportunities }\end{array}$ & & & & $(2.75)$ & & $(2.20)$ & & $(2.3 \mathrm{I})$ & $(2.64)$ \\
\hline Level I & & & & & $(3.50)$ & $(4.00)$ & & $(3.70)$ & $(3.70)$ \\
\hline Level 2 & & & & & $(3.10)$ & $(2.20)$ & & $(2.40)$ & $(2.40)$ \\
\hline $\begin{array}{l}\text { London } \\
\text { (ordinary) }\end{array}$ & & & & & 0.30 & $(1.00)$ & & $(1.00)$ & $(1.00)$ \\
\hline London (AIM) & & & & & 4.30 & 5.00 & & 5.80 & 5.80 \\
\hline Tax shield & & & & & & & $(0.20)$ & $(0.29)$ & $(0.32)$ \\
\hline NDTS & & & & & & & 0.08 & 0.32 & $(0.2 I)$ \\
\hline
\end{tabular}

Sum of statistically significant coefficients - economic significance $(\%)-200 \mathrm{I}-2007$

$\begin{array}{lllllll}(0.26) & (0.63) & 1.63 & (2.75) & (1.82) & (2.24) & (2.94)\end{array}$

Table 4 reports firm-fixed effect estimates of the impact of firm-level fundamentals, international cross-listing and tax-related factors on debt ratios of Irish firms from 1980 to 2007. Debt is market debt. Market debt is calculated as total debt to market value of assets, where market value of assets is equal to total book assets less the book value of equity plus market capitalisation. All other firm-level variables are defined in the main text. All firm-level variables are sourced from Worldscope. Level I and Level 2 are dummy variables representing whether a firm is cross-listed in the US either as a Level I over-the-counter issue or as an exchange-traded Level 2/3 ADR. London (ordinary) and London (AIM) are dummy variables, which are I if the firms are cross-listed in London as either an ordinary or AIM listing. All information on US cross-listed firms is sourced from the Bank of New York, and is cross-referenced with information from Citibank, JP Morgan Chase, the New York Stock Exchange and Nasdaq. Information on UK cross-listings is sourced from the London Stock Exchange.A full set of year (except for column 9) and firm-fixed effects are included, but not reported.The t-statistics are calculated using bootstrapped standard 
errors (200 replications). The standard errors are adjusted for clustering at the firm-level. The R-Squared is the overall R-Squared.\# Obs is the number of firm/year observations. ***,**, Denotes significance at the $1 \%, 5 \%$, and $10 \%$ level, respectively. In the remaining rows of Table 2, the economic significance of each of the firm-fundamentals, cross-listing and tax-related factors are calcuated. Estimates of economic significance are presented for three periods, namely the total period (1980-2007), from 1980 to 200I, and from $200 \mathrm{I}$ to 2007 . Bold indicates that the estimates are also statistically significant at conventional levels.

profitability, size and growth. The average change in firm-level profitability is 0.017 while the regression coefficient is -0.14 . This indicates that the increase in profitability is associated with a decrease in the average debt ratio of 0.24 percentage points (i.e. $\left.(0.017 *-0.14)^{*} 100\right)$ (or -0.41 when all variables are included simultaneously). Again, the results are statistically significant at the $1 \%$ level and of the expected sign. The regression coefficient on size of 0.032 and the increase of the within-firm trend of 2.82 indicate that the increase in size is associated with an increase in the average debt ratio of 9.02 percentage points (i.e. $(0.032 * 2.82) * 100)$ (or lower at 6.49 percentage points when all variables are included together). The results are again significant at the $1 \%$ level. We calculate the same estimate of economic significance for growth opportunities and find that the average change in firm-level growth opportunities is associated with a decrease in the average debt ratio of 3.65 percentage points (3.65 percentage points in column 9). Again, the results are statistically significant at the $1 \%$ level. Although all the variables are highly statistically significant, when market debt is the dependent variable, the effects of size and growth opportunities seem to be the most economically significant.

We repeat our analysis from Table 3 by dividing our sample into two sub-sample periods. In this case, all of the variables from our sub-samples are statistically significant. We begin by comparing our results for tangibility from the two sub-samples. In both cases, the coefficient is negative and statistically significant. However, the coefficient from the earlier sub-sample (see Panel C of Table 4) is more negative than that from the later sub-sample (see Panel D of Table 4), although neither is economically significant ( 0.15 and 0.06 , respectively). Next, we consider profitability. For our earlier sub-sample (1980-2001), the estimate of economic significance is 0.39, indicating that the change in the within-firm profitability trend between 1980 and 2001 is associated with an increase in the average debt ratio of just 0.39 percentage points (or 0.68 when all variables are included together without time-fixed-effects). When examining the later sub-sample, again we find the opposite. The estimate of economic significance of profitability from 2001 to 2007 is -0.63 , indicating that the change in the within-firm profitability is associated with a decrease in the average debt ratio of 0.63 percentage points (or -1.09 in column 9). When we consider what happens to size over our two sub-sample periods, our estimate of economic significance is positive and significant across both samples. When we look at the earlier sample period, we find that an increase in the within-firm trend is associated with an increase in the average debt ratio of 7.39 percentage points (5.31 percentage points in column 9). The estimate of economic significance for the latter sample period indicates that an increase in the within-firm trend is associated with an increase in the average debt ratio of just 1.63 percentage points (1.17 percentage points in column 9). Hence, as when examining book debt, size predicts an increased debt usage in both sub-periods and as such can only explain the pre2001 run-up in debt ratios, but not a great deal of what happens thereafter. Finally, 
the economic significance of growth opportunities for the earlier sample period is -0.90 (-0.86 in column 9). This coefficient becomes substantially more negative over the later sub-sample period, at an estimate of -2.75 (or -2.64 percentage points in column 9). Across both sub-samples, the effects of size (in the pre-2001 period) and growth opportunities (in the post-2001 period) seem to be the most economically significant of the firm-fundamentals. However, a caveat is in order, and one must be careful in interpreting the significance of the growth opportunities in market-debt regressions. The reason is that both variables are likely to be related mechanically since, in their construction, the numerator of market debt and the denominator of growth opportunities are the same, which would impart a negative relationship between the two.

The results from our previous analysis show that some of the changes in debt ratios in Ireland can, in part, be explained by firm-fundamentals. While they appear to do a very good job in explaining the increased use of debt by Irish firms prior to 2001, they explain very little of the post-2001 decline. With this in mind, we turn to country-level factors and examine whether these factors can explain the post2001 fall in debt usage by Irish firms. The variables we consider are credit-market development, stock-market development, financial openness and creditor rights. The dependent variable is book value of debt. We include GDP per capita as a control, although its inclusion is problematic since it tends to be highly correlated (presumably because of the inclusion of GDP as a numerator in many of the other country-level variables) with many of the other country-level variables. For example, the correlation coefficient between GDP per capita, credit-market development and financial openness is 0.904 and 0.876 , respectively. Consider also that the variance inflation factor from estimating a regression of GDP per capita, with all four country-level variables as independent variables, is high at 14.81. Consequently, we estimate a series of regressions with and without GDP per capita. The results are presented in Table 5 (using book debt) and 6 (using market debt). Column 1 of Table 5 (see Panel A) shows a positive relationship between stock-market development and debt ratios. This implies that a more highly developed stock market is associated with higher, not lower, firm-debt levels than one might expect. The results are statistically significant at the $1 \%$ level. In column 2 , and contrary to our expectations, we find a negative coefficient on our credit-market development variable. We would expect the coefficient to be positive here as more developed credit markets allow firms easier access to external finance. The reason for the negative coefficient is most likely due to the inclusion of GDP per capita as a control variable in the regression. Furthermore, when we run the regression without GDP per capita (as reported in column 6), the coefficient on credit-market development is positive, but no longer statistically significant.

In column 3, we find a positive and significant coefficient on financial openness, indicating that increasing levels of financial openness are associated with higher debt levels. This is unsurprising as increased financial openness allows firms easier access to raising funds abroad. Increasing financial openness gives firms a greater set of financing options and increases competition among credit providers, potentially decreasing the cost of capital to firms. Finally, we consider the effect of creditor rights on debt ratios. The results are shown in column 4 . We find a positive 
Which Factors Determine the Capital Structure of Non-Financial Publicly Traded Irish Firms?

TABLE 5: COUNTRY/LEGAL FACTORS AND DEBT RATIOS

\begin{tabular}{|c|c|c|c|c|c|c|}
\hline \multirow{3}{*}{ Panel A } & \multicolumn{6}{|c|}{ Book debt } \\
\hline & \multicolumn{4}{|c|}{$\begin{array}{l}\text { Supply-side financial-sector variables \& } \\
\text { creditor rights }\end{array}$} & \multirow{2}{*}{$\begin{array}{l}\text { All } \\
\text { (5) } \\
\end{array}$} & \multirow{2}{*}{$\begin{array}{c}\text { All excl. } \\
\text { GDP } \\
(6)\end{array}$} \\
\hline & ( & $(2)$ & (3) & (4) & & \\
\hline Stock-market development & $\begin{array}{c}0.085^{* * * *} \\
(2.66)\end{array}$ & & & & $\begin{array}{l}0.035 \\
(0.95)\end{array}$ & $\begin{array}{l}0.072^{* *} \\
(2.01)\end{array}$ \\
\hline Credit-market development & & $\begin{array}{c}-0.079 * * * \\
(2.72)\end{array}$ & & & $\begin{array}{l}-0.066^{*} \\
(1.94)\end{array}$ & $\begin{array}{l}0.017 \\
(0.94)\end{array}$ \\
\hline Financial openness & & & $\begin{array}{l}0.015 * * \\
(2.14)\end{array}$ & & $\begin{array}{l}0.013 \\
(1.44)\end{array}$ & $\begin{array}{c}0.025^{* * * *} \\
(3.25)\end{array}$ \\
\hline Creditor rights & & & & $\begin{array}{l}0.022 \\
(1.42)\end{array}$ & $\begin{array}{l}0.038^{*} \\
(1.90)\end{array}$ & $\begin{array}{l}0.020 \\
(1.21)\end{array}$ \\
\hline GDP per capita & $\begin{array}{l}0.072 * * * \\
(5.14)\end{array}$ & $\begin{array}{l}0.161^{* * * *} \\
(5.75)\end{array}$ & $\begin{array}{l}0.052 * * \\
(2.36)\end{array}$ & $\begin{array}{l}0.101 * * * \\
(5.67)\end{array}$ & $\begin{array}{l}0.134^{* * * *} \\
(2.73)\end{array}$ & \\
\hline \# Obs & 763 & 763 & 763 & 763 & 763 & 763 \\
\hline R-squared & 0.013 & 0.016 & 0.014 & 0.010 & 0.018 & 0.015 \\
\hline Year dummies & No & No & No & No & No & No \\
\hline
\end{tabular}

Panel B

Estimates of economic significance (\%) - total period

\begin{tabular}{lcccccc} 
& $(\mathbf{I})$ & $(\mathbf{2})$ & $\mathbf{( 3 )}$ & $\mathbf{( 4 )}$ & $\mathbf{( 5 )}$ & $\mathbf{( 6 )}$ \\
\hline Stock-market development & 2.73 & & & & 1.12 & $\mathbf{2 . 3 \mathrm { I }}$ \\
Credit-market development & & $(10.74)$ & & & $\mathbf{( 8 . 9 9 )}$ & 2.31 \\
Financial openness & & & 3.95 & & 3.42 & $\mathbf{6 . 5 8}$ \\
Creditor rights & & & & $(2.22)$ & $\mathbf{( 3 . 8 0 )}$ & $(2.00)$
\end{tabular}

Sum of statistically significant coefficients - economic significance (\%)

$\begin{array}{lllll}2.73 & (10.74) & 3.95 & (12.79) & 8.89\end{array}$

\begin{tabular}{lcccccc}
\hline \multicolumn{1}{c}{ Panel C } & \multicolumn{2}{c}{ Estimates of economic significance (\%) $-1980-200$ I } \\
& $(\mathbf{l})$ & $\mathbf{( 2 )}$ & $\mathbf{( 3 )}$ & $\mathbf{( 4 )}$ & $\mathbf{( 5 )}$ & $\mathbf{( 6 )}$ \\
\hline Stock-market development & 4.43 & & & & 1.82 & 3.75 \\
Credit-market development & & $(4.66)$ & & & $\mathbf{( 3 . 8 9 )}$ & 1.00 \\
Financial openness & & & 3.95 & & 3.42 & $\mathbf{6 . 5 8}$ \\
Creditor rights & & & & $(2.22)$ & $\mathbf{( 3 . 8 0 )}$ & $(2.00)$
\end{tabular}

Sum of statistically significant coefficients - economic significance (\%)

\begin{tabular}{lcccccc} 
& 4.43 & $(4.66)$ & 3.95 & \multicolumn{2}{c}{$(7.69)$} & 10.33 \\
\hline \multicolumn{1}{c}{ Panel D } & \multicolumn{2}{c}{ Estimates of economic significance (\%) $-\mathbf{2 0 0}$} & I-2007 \\
& $(1)$ & $(\mathbf{2})$ & $\mathbf{( 3 )}$ & $\mathbf{( 4 )}$ & $\mathbf{( 5 )}$ & $\mathbf{( 6 )}$ \\
\hline Stock-market development & $(1.70)$ & & & & $(0.30)$ & $\mathbf{( 1 . 4 4 )}$ \\
Credit-market development & & $(6.08)$ & & & $\mathbf{( 5 . 0 8 )}$ & 1.31 \\
Financial openness & & & 0.00 & & 0.00 & 0.00 \\
Creditor rights & & & & $(2.22)$ & $\mathbf{( 3 . 8 0 )}$ & $(2.00)$
\end{tabular}

Sum of statistically significant coefficients - economic significance (\%)

$\begin{array}{llll}(1.70) \quad(6.08) & (8.88) \quad(1.44)\end{array}$

(Continued) 
Table 5 reports firm-fixed effect estimates of the impact of country/legal factors on debt ratios of Irish firms from 1980 to 2007. Debt is measured as total debt to total assets (book value of debt). All country-level variables are defined in the main text. Creditor rights are from Djankov et al. (2007). Stock and credit-market development data is sourced from the World Bank and the Central Bank of Ireland. (Log) GDP per capita is sourced from EcoWin and the Central Bank of Ireland.A full set of firm-fixed effects are included, but not reported.Time-fixed effects are excluded. The t-statistics are calculated using bootstrapped standard errors (200 replications). The R-squared is the overall R-Squared.\# Obs is the number of firm/year observations. ***,**,* Denotes significance at the $1 \%, 5 \%$, and $10 \%$ level, respectively. In the remaining rows of Table 3, the economic significance of each of the country-level factors are calculated. Estimates of economic significance are presented for three periods, namely the total period (1980-2007), from I 980 to 200 I, and from 200 I to 2007 . Bold indicates that the estimates are also statistically significant at conventional levels.

coefficient, implying that creditor rights and leverage move in the same direction, although the results are not statistically significant. When we include all countrylevel factors in the regression, stock-market development and financial openness remain statistically significant. The results are shown in column 6 . The coefficient on stock-market development is 0.072 and is statistically at the $5 \%$ level. The coefficient of 0.025 on financial openness is statistically significant at the $1 \%$ level.

Next, we examine the economic significance of the country-level factors on firm-debt ratios. Initially, we consider the economic significance of each variable over the entire sample period (see Panel B of Table 5). Then we divide the sample into two sub-sample periods. Across the entire sample period, we find three of the explanatory variables to be economically significant, namely stock-market development, credit-market development and financial openness, although in regressions that include all variables simultaneously, credit-market development is no longer statistically significant. Together, stock-market development (2.31) and financial openness (6.58) suggest an increase in book debt over the full sample period of 8.89 percentage points. Neither credit-market development nor creditor rights is statistically significant. These country-level variables together with their firm-level counterparts suggest an increase in book debt in the region of 19.46 percentage points (i.e. 10.57 (see Panel B of Table 3) + 8.89 (see Panel B of Table 5)) over the entire sample period. In the case of the country-level variables, the 8.89 percentagepoint increase involves an increase of 10.33 (stock-market development is 2.31 and financial openness is 6.58) in the period up to 2001, and a decrease of 1.44 post-2001. Taken together, the firm- and country-level variables imply an increase in book debt in the region of 20.04 in the period leading up to 2001 (i.e. 9.71 (see Panel C of Table 3) +10.33 (see Panel C of Table 5)), much more than the actual increase of 12 percentage points. Interestingly, while firm-and country-level variables can, either individually or collectively, explain all and more of the actual increase in bookdebt financing to 2001, neither can account for the decline in book-debt usage since 2001. For example, when we sum the statistically significant firm- and country-level variables together, the result is a negative 0.59 percentage points $(0.85+(1.44))$ (see Panels D of Tables 3 and 5).

Table 6 presents the coefficient estimates using market debt. Here, when all variables are included simultaneously, only financial openness and creditor rights remain statistically significant (see Panel A of Table 6). Together they explain almost none of the increases in market debt to 2001 since their effects tend to cancel out one another (see Panel C of Table 6). Specifically, the coefficient estimate on financial 
Which Factors Determine the Capital Structure of Non-Financial Publicly Traded Irish Firms?

TABLE 6: COUNTRY/LEGAL FACTORS AND DEBT RATIOS

\begin{tabular}{|c|c|c|c|c|c|c|}
\hline \multirow{3}{*}{ Panel A } & \multicolumn{6}{|c|}{ Market debt } \\
\hline & \multicolumn{4}{|c|}{$\begin{array}{l}\text { Supply-side financial sector variables } \\
\qquad \& \text { creditor rights }\end{array}$} & \multirow{2}{*}{$\begin{array}{l}\text { All } \\
\text { (5) }\end{array}$} & \multirow{2}{*}{$\begin{array}{c}\text { All excl. } \\
\text { GDP } \\
(6)\end{array}$} \\
\hline & $(\mathrm{I})$ & (2) & (3) & (4) & & \\
\hline Stock-market development & $\begin{array}{l}0.043 \\
(1.23)\end{array}$ & & & & $\begin{array}{l}-0.040 \\
(1.00)\end{array}$ & $\begin{array}{l}0.024 \\
(0.62)\end{array}$ \\
\hline Credit-market development & & $\begin{array}{c}-0.100 * * * \\
(3.61)\end{array}$ & & & $\begin{array}{c}-0.153 * * * \\
(4.37)\end{array}$ & $\begin{array}{l}-0.010 \\
(0.67)\end{array}$ \\
\hline Financial openness & & & $\begin{array}{l}-0.004 \\
(0.50)\end{array}$ & & $\begin{array}{l}-0.010 \\
(1.11)\end{array}$ & $\begin{array}{l}0.015^{* *} \\
(2.14)\end{array}$ \\
\hline Creditor rights & & & & $\begin{array}{c}0.047^{* * *} \\
(2.65)\end{array}$ & $\begin{array}{c}0.07 \mid * * * \\
(3.23)\end{array}$ & $\begin{array}{c}0.04 I^{* * *} \\
(1.96)\end{array}$ \\
\hline GDP per capita & $\begin{array}{l}0.015 \\
(0.96)\end{array}$ & $\begin{array}{c}0.115^{* * * *} \\
(3.59)\end{array}$ & $\begin{array}{l}0.032 \\
(1.39)\end{array}$ & $\begin{array}{c}0.052^{* * * *} \\
(3.06)\end{array}$ & $\begin{array}{c}0.232^{* * * *} \\
(4.64)\end{array}$ & \\
\hline \# Obs & 763 & 763 & 763 & 763 & 763 & 763 \\
\hline R-squared & 0.001 & 0.006 & 0.001 & 0.003 & 0.016 & 0.010 \\
\hline Year dummies & No & No & No & No & No & No \\
\hline \multirow[t]{2}{*}{ Panel B } & \multicolumn{6}{|c|}{ Estimates of economic significance (\%) - total period } \\
\hline & $(\mathrm{I})$ & (2) & (3) & (4) & (5) & \\
\hline Stock-market development & 1.38 & & & & $(1.28)$ & 0.77 \\
\hline Credit-market development & & $(13.60)$ & & & $(20.81)$ & $(1.36)$ \\
\hline Financial openness & & & $(1.05)$ & & $(2.63)$ & 3.95 \\
\hline Creditor rights & & & & $(4.70)$ & $(7.10)$ & $(4.10)$ \\
\hline
\end{tabular}

Sum of statistically significant coefficients - economic significance (\%)

(13.60)

(4.70)

(27.9l)

$(0.15)$

\begin{tabular}{lcccccc}
\hline \multicolumn{1}{c}{ Panel C } & \multicolumn{5}{c}{ Estimates of economic significance (\%) - I 980-200 I } \\
& (1) & (2) & (3) & (4) & (5) & \\
\hline Stock-market development & 2.24 & & & & $(2.08)$ & 1.25 \\
Credit-market development & & $(5.90)$ & & & $\mathbf{( 9 . 0 3 )}$ & $(5.90)$ \\
Financial openness & & & $(1.05)$ & & $(2.63)$ & 3.95 \\
Creditor rights & & & & $(4.70)$ & $(7.10)$ & $(4.10)$
\end{tabular}

Sum of statistically significant coefficients - economic significance (\%)

(5.90)

(4.70)

$(16.13) \quad(0.15)$

\begin{tabular}{lcccccc}
\hline \multicolumn{1}{c}{ Panel D } & \multicolumn{5}{c}{ Estimates of economic significance (\%) - 200 I-2007 } \\
& $(\mathbf{I})$ & $\mathbf{( 2 )}$ & $\mathbf{( 3 )}$ & $\mathbf{( 4 )}$ & $\mathbf{( 5 )}$ & \\
\hline Stock-market development & $(15.70)$ & & & & $(0.80)$ & $(0.48)$ \\
Credit-market development & & $(7.70)$ & & & $(11.78)$ & $(7.70)$ \\
Financial openness & & & 0.00 & & 0.00 & 0.00 \\
Creditor rights & & & & $(4.70)$ & $(7.10)$ & $(4.10)$
\end{tabular}

Sum of statistically significant coefficients - economic significance (\%) (7.70) (4.70) (I8.88) (4.10) 
Table 6 reports firm-fixed-effect estimates of the impact of country/legal factors on debt ratios of Irish firms from 1980 to 2007. Debt is measured using market debt. Market debt is calculated as total debt to market value of assets, where market value of assets is equal to total book assets less the book value of equity plus market capitalisation. All country-level variables are defined in the main text. Creditor rights are from Djankov et al. (2007). Stock and credit-market development data is sourced from the World Bank and the Central Bank of Ireland. (Log) GDP per capita is sourced from EcoWin and the Central Bank of Ireland. A full set of firm-fixed effects are included, but not reported. Time- fixed effects are excluded. The t-statistics are calculated using bootstrapped standard errors (200 replications). The R-Squared is the overall R-Squared. \# Obs is the number of firm/year observations. ***, **, * Denotes significance at the $1 \%, 5 \%$, and $10 \%$ level, respectively. In the remaining rows of Table 4 , the economic significance of each of the country-level factors are calculated. Estimates of economic significance are presented for three periods, namely the total period (1980-2007), from I 980 to 200 I, and from 200 I to 2007. Bold indicates that the estimates are also statistically significant at conventional levels.

openness implies greater use of market debt in the region of 3.95 percentage points, while the fall in creditor rights suggests less debt financing in the region of 4.10 percentage points. If we assume that the change in creditor rights lingers beyond 2001, then the change in creditor rights explains at least part of the decrease in debt financing post-2001 (see Panel D of Table 6).

In summary, our findings suggest that fundamentals can help explain why firms became more indebted between 1980 and 2001, but the deleveraging that took place after 2001 is due to factors other than the fundamentals included in our analysis. So what may explain the deleveraging of Irish firms since 2001? First, it may be that factors, other than those specified, explain the deleveraging process. For example, Frank and Goyal (2009) explore the effects, among others, of dividend payout and firm-risk on corporate capital structures. Along similar lines, the deleveraging of non-financial European firms since 2008 largely reflects their greater propensity to save more (i.e. retain earnings) and thus rely less on external capital (European Central Bank, 2012). It may well be the case that Irish firms did likewise since 2001. ${ }^{16}$ A more plausible explanation, and one that is supported by anecdotal evidence, is that managers made a concerted effort to reduce debt, even when fundamentals suggested otherwise. We theorise that this has been done in an effort to build up debt capacity for the future. Although the levels of debt amassed up to the 2001 period were nowhere near the levels that would induce financial distress, debt levels were sufficiently high as to leave firms vulnerable in the event of a future negative external shock. If such an event were to materialise (as happened during the recent financial crisis), the value of balance-sheet assets would fall rapidly, leaving firms unable to service their growing debt burden. Although there is insufficient data available to empirically test this hypothesis, there is some evidence that nonfinancial Irish firms have sold part of their businesses to reduce their debt levels. For example, in 2003, Independent News and Media announced a rights issue and sold part of its regional UK newspaper business to establish 'a greatly fortified capital structure for your group', in order to return the firm's debt to 'invesmtent grade status' (Evening Standard, 2003). Also in 2003, The Guardian reported that 'Elan plans sale to cut debt burden' (Guardian, 2003). In fact, since then, both of these companies have continued to engage in similar actions to reduce their debt holdings: in 2011, for example, Elan sold its EDT unit and reported that it was a positive move for shareholders as it 'reduced the company's debt and improved its capital structure'.

It is also possible that the speed at which credit constraints were loosened in the Irish market and the ease with which finance could be accessed caused managers 
to reduce their debt capacity in order to send a signal to investors that firms were acting responsibly by building up debt capacity for the future.

The fact that fundamental factors cannot explain the period of deleveraging from 2001 onwards raises the opportunity to explore why managers made a choice to reduce debt. There is currently no data available to explain why this is the case and hence is beyond the scope of this paper. Future work could adopt a surveybased approach to shed further light on this issue.

\section{CONCLUSION}

In this paper we have examined whether fundamental factors can explain the use of debt financing by non-financial Irish firms. Using data for 56 non-financial firms, we examine the period 1980 to 2007 and find that Irish non-financial firms are no more indebted than the European average. Furthermore, we find that the median Irish non-financial firm is no more indebted at the end of our sample period, 2007, than at the beginning, 1980. Debt ratios increased initially, and reached a peak in 2001. Following this, there was a period of deleveraging resulting in debt ratios falling to pre-1980s levels. Our findings suggest that fundamental factors can explain the use of debt financing up to 2001, but do not explain the subsequent deleveraging. While the deleveraging may be explained by factors that we do not account for, we believe it is more than likely explained by the fact that financial managers made a conscious choice to reduce debt ratios, for reasons other than the fundamental factors that we explore. The reasons why financial managers chose to do this may be because they felt that their firm was too highly indebted. High levels of debt can leave firms more vulnerable to economic downturns because required debt repayments can be difficult to scale back. During economic downturns, firms may be forced to put off long-run investments to sustain short-run operations and this can ultimately lead to a fall in productivity and a rejection of profitable investment opportunities. Deleveraging serves to build debt capacity, which insures that where investment opportunities are identified, they can be financed.

\section{ENDNOTES}

1 If only the supply of debt financing is reduced, firms can substitute debt for equity financing. However, where the supply of debt and equity financing are both compromised, firms can no longer perform this substitution, which results in a loss of investment opportunities and an ultimate reduction in corporate net worth (see Kahle and Stulz, 2012).

2 Mac an Bhaird and Lucey (2010) explore the demand-side determinants of the capital structures of Irish small to medium-sized enterprises. Hogan and Hutson (2004) examine the capital structure of new Irish technology-based firms.

3 From 2007 onwards, credit-risk premia have increased as a result of poor economic growth and increased government indebtedness. We omit years after 2007 from our sample period as we are interested in examining the long term, and the inclusion of the financial-crisis period may distort our results.

4 Demirguc-Kunt and Maksimovic (1998) derive an expression for a firm's external financing need, which is a function of, among others, the retention ratio. All else being equal, the higher the retention ratio, the lower is the firm's external financing need.

$5 \quad$ See also Schmukler and Vesperoni (2006), and Flavin and O'Connor (2010). 
Byrne, McNally and O'Connor

6 We prefer to use sales, rather than total assets to proxy for firm-size, since the latter is used to construct a number of the firm-level variables employed in the analysis.

7 See Fama and French (2002) and Frank and Goyal (2003) for empirical tests of the pecking order hypothesis. For a more recent treatment, see Huang and Ritter (2009) and Lemon and Zender (2010). Lemon and Zender show that once a firm's debt capacity has been reached, a firm will tend resort to equity financing. Hence firms that appear to use predominantly more equity than debt financing may do so because of their low debt capacity. Once debt capacity is accounted for, the ability of the pecking order hypothesis to explain observed capital structure behaviour improves considerably.

8 Ultimately like others, our calculation of Tobin's $q$ deviates from the original definition, by proxying for the market value of debt using its book value counterpart, and measure the replacement cost of assets as the book value of assets.

9 The primary drawback of using this data item is that it only dates from 1996 to 2005 . To complete the series, we do the following. Using market capitalisation data of Irish firms from Worldscope, we estimate the within-firm trend over time from the coefficients on the year dummies from the following regression: MCap $_{\mathrm{it}}=\alpha+$ Firm $_{\mathrm{i}}+$ Year $_{\mathrm{t}}+\varepsilon_{\mathrm{it}}$ and use these coefficients to work backwards and complete the blanks in the Beck et al. (2000) database.

10 However, others have shown that stock-market development is associated with greater use of debt financing, or more precisely long-term debt financing (see Demirguc-Kunt and Maksimovic (1995) and Demirguc-Kunt and Levine (1996)). In a similar vein, Flavin and O'Connor $(2010,2013)$ show how stock-market liberalisations result in the greater use of long-term debt for some firms.

11 Of course, this does not rule out the possibility that a Level 1 or Level 2 exchange-listing does not impact on the capital structure of Irish firms. For example, the legal bonding hypothesis suggests that post-listing, firms will have a lower cost of capital (see Coffee (1999, 2002); Stulz (1999); Hail and Leuz (2009)). In turn, firms may and do issue more debt and equity, not necessarily in the US, but domestically (see Reese and Weisbach (2002)) as a result of this lower cost of capital. Consequently, cross-listing does serve to reduce financing constraints (see Lins et al. (2005)) and foster growth (see Khurana, Martin and Periera (2008)).

12 In this regard, Flavin and O'Connor (2010) show how the post-cross-listing capital issuance choice is related to whether a firm was previously deemed investable or not. While, on average, firms use less debt post-listing, they show that firms, most notably Level 2 firms that were previously deemed investable, use more debt financing. Level 2 firms that were not previously investable use more equity-financing, post-listing.

13 Worldscope coverage of Irish firms has increased dramatically over time, ranging from just 11 firms (in our final sample) to over 60 firms in the latter part of my sample period.

14 Note that the median firm is more indebted in 2007 than in 1980, but the within-firm trend suggests otherwise. Given the radical changes in sample composition over our sample period, we prefer to place greater emphasis on the trend measure.

15 What remains interesting from Figure 1 is that the increased use of debt was not just interest-bearing debt (given the increase in total liabilities to total assets), and followed an increased use of trade credit (unreported), which has remained high throughout the sample period. This shift towards debt financing (given the increased use of trade credit in an earlier perod) is consistent with Berger and Udell's (1998) financial life-cycle growth model.

16 Due to data availability issues, we cannot observe the retained earnings position of Irish firms over the sample period. What we can observe is the dividend payout (using dividends to earnings) of these firms over the sample period. While the payout (retention) ratio has fallen (risen) since 2001, the fall in the payout ratio has been steady since 1980. For example, between 1980 and 2001 (and controlling for changes in sample composition), the payout ratio has fallen by 5 per cent.

\section{REFERENCES}

Almeida, H., Campello, M., Larenjera, B. and Weisbenner, S. (2011). Corporate Debt Maturity and the Real Effects of the 2007 Credit Crisis, Critical Finance Review, Vol. 1, pp. 3-58.

Beck, T., Demirguc-Kunt, A. and Levine, R. (2000). A New Database on Financial Development and Structure,World Bank Economic Review, Vol. 14, pp. 597-605. 
Which Factors Determine the Capital Structure of Non-Financial Publicly Traded Irish Firms?

Berger, A. and Udell, G. (1998). The Economics of Small Business Finance: The Roles of Private Equity and Debt Markets in the Financial Growth Cycle, Journal of Banking and Finance, Vol. 22, pp. 613-673.

Booth, L., Aivazian, V., Demirguc-Kunt, A. and Maksimovic, V. (2001). Capital Structure in Developing Countries, Journal of Finance, Vol. 56, pp. 87-130.

Bradley, M., Jarrell, G. and Kim, E. (1984). On the Existence of an Optimal Capital Structure: Theory and Evidence, Journal of Finance, Vol. 39, pp. 857-78.

Cecchetti, S., Mohanty, M. and Zampolli, F. (2011). The Real Effects of Debt, Working Paper No. 352, Bank of International Settlements.

Chinn, M. and Ito, H. (2008). A New Measure of Financial Openness, Journal of Comparative Policy Analysis, Vol. 10, pp. 309-322.

Claessens, S., Djankov, S. and Xu, L. (2000). Corporate Performance in the East Asian Financial Crisis, World Bank Research Observer, Vol. 15, pp. 23-46.

Coffee, J. (1999). The Future as History: The Prospects for Global Convergence in Corporate Governance and its Implications, Northwestern University Law Review, Vol. 93, pp. 641-708.

Coffee, J. (2002). Racing Towards the Top: The Impact of Cross-listings and Stock Market Competition on International Corporate Governance, Columbia Law Review, Vol. 102, pp. 1757-1832.

Custodio, C., Ferreira, M. and Laureano, L. (2012). Why are U.S. Firms Using More Shortterm Debt?, Journal of Financial Economics, Vol. 108, pp. 182-212.

Cussen, M. and O'Leary, B. (2013). Why Are Irish Non-financial Corporations so Indebted?, Quarterly Bulletin 1, Central Bank of Ireland.

DeAngelo, H. and Masulis, R. (1980). Optimal Capital Structure under Corporate and Personal Taxation, Journal of Financial Economics, Vol. 8, pp. 139-78.

De Jong, A., Kabir, R. and Nguyen, T.T. (2008). Capital Structure around the World: The Roles of Firm-and Country-specific Determinants, Journal of Banking and Finance, Vol. 32, pp. 1954-1969.

Demirguc-Kunt, A. and Maksimovic, V. (1995). Stock Market Development and Firm Financing Policies, working paper, World Bank.

Demirguc-Kunt, A. and Maksimovic, V. (1995). Law, Finance and Firm Growth, Journal of Finance, Vol. 53, pp. 2107-2131.

Demirguc-Kunt, A. and Levine, R. (1996). Stock Market Development and Financial Intermediaries: Stylized Facts, World Bank Economic Review, Vol. 10, pp. 291-321.

Demirguc-Kunt, A. and Maksimovic, V. (1999). Institutions, Financial Markets and Firm Debt Maturity, Journal of Financial Economics, Vol. 54, 295-336.

Devos, E., Dhillon, U., Jagannathan, M. and Krishnamurthy, S. (2012). Why Are Firms Unlevered?, Journal of Corporate Finance, Vol. 18, pp. 664-682.

Djankov, S., McLiesh, C. and Shleifer, A. (2007). Private Credit in 129 Countries, Journal of Financial Economics, Vol. 84, pp. 299-329.

Duchin, R., Ozbas, O. and Sensoy, B. (2010). Costly External Finance, Corporate Investment, and the Subprime Mortgage Credit Crisis, Journal of Financial Economics, Vol. 97, pp. 418-435.

European Central Bank (2012). Corporate Indebtedness in the Euro Area, European Central Bank Monthly Bulletin (February), pp. 87-103.

Fama, E. and French, K. (2002). Testing Tradeoff and Pecking Order Predictions about Dividends and Debt, Review of Financial Studies, Vol. 15, pp. 1-33.

Fan, J., Titman, S. and Twite, G. (2012). An International Comparison of Capital Structure and Debt Maturity Choices, Journal of Financial and Quantitative Analysis, Vol. 47, pp. 23-56.

Flavin, T. and O'Connor, T. (2010). The Sequencing of Stock Market Liberalization Events and Corporate Financing Decisions, Emerging Market Review, Vol. 11, pp. 183-204. 
Byrne, McNally and O'Connor

Flavin, T. and O'Connor, T. (2013). The Effects of Ownership Structure on Corporate Financing Decisions: Evidence from Stock Market Liberalization, working paper, NUI Maynooth.

Frank, M. and Goyal, V. (2003). Testing the Pecking Order Theory of Capital Structure, Journal of Financial Economics, Vol. 67, pp. 217-48.

Frank, M. and Goyal, V. (2009). Capital Structure Decisions: Which Factors Are Reliably Important?, Financial Management, Vol. 38, pp. 1-37.

Gozzi, J., Levine, S. and Schmukler, S. (2009). Patterns of International Capital Raisings, Journal of International Economics, Vol. 80, pp. 45-57.

Gozzi, J., Levine, S., Peria, M. and Schmukler, S. (2012). How Firms Use Domestic and International Bond Markets, Working paper, Brown University.

Graham, J. (2003). Taxes and Corporate Finance: A Review, Review of Financial Studies, 16, pp. 1074-1128.

Hail, L. and Leuz, C. (2009). Cost of Capital Effects and Changes in Growth Expectations around U.S. Cross-listings, Journal of Financial Economics, Vol. 93, pp. 428-454.

Harvey, C. and Roper, A. (1999). The Asian Bet in A. Harwood, R. Litan and M. Pomerleano (eds), The Crisis in Emerging Financial Markets, Brookings Institute Press, pp. 29-115.

Henderson, B., Jegadeesh, N. and Weisbach, M. (2006). World Markets for Raising New Capital, Journal of Financial Economics, Vol. 82, pp. 63-101.

Hogan, T. and Hutson, E. (2004). Capital Structure in New Technology-based Firms: Evidence from the Irish Software Sector, Global Finance Journal, Vol. 15, pp. 369-387.

Huang, R. and Ritter, J.R. (2009). Testing Theories of Capital Structure and Estimating the Speed of Adjustment, Journal of Financial and Quantitative Analysis, Vol. 44, pp. 237-271.

International Monetary Fund (2013). Global Financial Stability Report: Old Risks New Challenges, International Monetary Fund, World Economic and Financial Surveys.

Jensen, M. (1986). Agency Costs of Free-cash Flow, Corporate Finance, and Takeovers, The American Ecoonomic Review, Vol. 76, pp. 323-329.

Kahle, K. and Stulz, R. (2012). Access to Capital, Investment and the Financial Crisis, working paper 2012-2, Fisher College of Business, Ohio State University.

Kester, G. and Robbins, G. (2011). Financial Policies and Practices of Companies Listed on the Irish Stock Exchange: Capital Structure, Dividends and Capital Budgeting, Irish Accounting Review, 17, pp. 65-94.

Khurana, I., Martin, X. and Periera, R. (2008). Cross-listing and Firm-growth, Review of Finance, Vol. 12, pp. 293-322.

Krugman, P. (1999). Balance Sheets, the Transfer Problem and Financial Crises in A. Razin and a. Rose (eds), International Finance and Financial Crises; Essays in Honor of Robert P. Flood $J r$, Kluwer Academic Publishers, AA Dordrecht, The Netherlands, pp. 31-44.

Lemmon, M. and Zender, J. (2010). Debt Capacity and Tests of Capital Structure Theories, Journal of Financial and Quantitative Analysis, Vol. 45, pp. 1161-1187.

Lins, K., Strickland, D. and Zenner, M. (2005). Do Non-U.S. Firms Issue Equity on U.S. Stock Exchanges to Relax Capital Constraints?, Journal of Financial and Quantitative Analysis, Vol. 40, pp. 109-133.

Mac an Bhaird, C. and Lucey, B. (2010). Determinants of Capital Structure in Irish SMEs, Small Business Economics, Vol. 35, pp. 357-375.

McKinsey \& Co. (2012). Debt and Deleveraging: Uneven Progress on the Path to Growth, McKinsey \& Co.

Mitton, T. (2007). Why Have Debt Ratios Increased for Firms in Emerging Markets?, European Financial Management, Vol. 14, pp. 127-151.

Myers, S. (1977). Determinants of Corporate Borrowing, Journal of Financial Economics, Vol. 5, pp. 147-75. 
Which Factors Determine the Capital Structure of Non-Financial Publicly Traded Irish Firms?

Myers, S. and Majluf, N. (1984). Corporate Financing and Investment Decisions when Firms Have Information that Investors Do not Have, Journal of Financial Economics, Vol. 13, pp. 187-221.

Rajan, R. and Zingales, L. (1995). What Do we Know about Capital Structure? Some Evidence from International Data, Journal of Finance, Vol. 50, pp. 1421-1460.

Reese, W. and Weisbach, M. (2002). Protection of Minority Shareholder Interests, Cross-listings in the United States, and Subsequent Equity Offerings, Journal of Financial Economics, Vol. 66, pp. 65-104.

Schmukler, S. and Vesperoni, E. (2006). Financial Globalization and Debt Maturity in Emerging Markets, Journal of Development Economics, Vol. 79, pp. 183-207.

Scott, J. (1977). Bankruptcy, Secured Debt, and Optimal Capital Structure, Journal of Finance, Vol. 32, pp. 1-19.

Strebulaev, I. and Yang, B. (2012). The Mystery of Zero-leverage Firms, working paper, Stanford University.

Stuart, R. (2006). Stylised Facts on Irish Corporate Balance Sheets, Financial Stability Report, Central Bank of Ireland, pp. 145-154.

Stulz, R. (1990). Managerial Discretion and Optimal Financial Policies, Journal of Financial Economics, Vol. 26, pp. 3-26.

Stulz, R. (1999). Globalization, Corporate Finance, and the Cost of Capital, Journal of Applied Corporate Finance, Vol. 12, pp. 8-25.

The Evening Standard (26 March 2003). Indy's O'Reilly Taps City, Sells Titles to Slash Debt, The Evening Standard.

The Guardian (31 October 2003). Elan Plans Sale to Cut Debt Burden, The Guardian.

Wald, J. (1999). How Firm Characteristics Affect Capital Structure: An International Comparison, Journal of Financial Research, Vol. 22 (2), pp. 161-187.

Vig, V. (2009). Access to Collateral and Corporate Debt Structure: Evidence From a Natural Experiment, Journal of Finance, Vol. 68, pp. 881-928. 